INTER NATIONAL MONETARY FUND
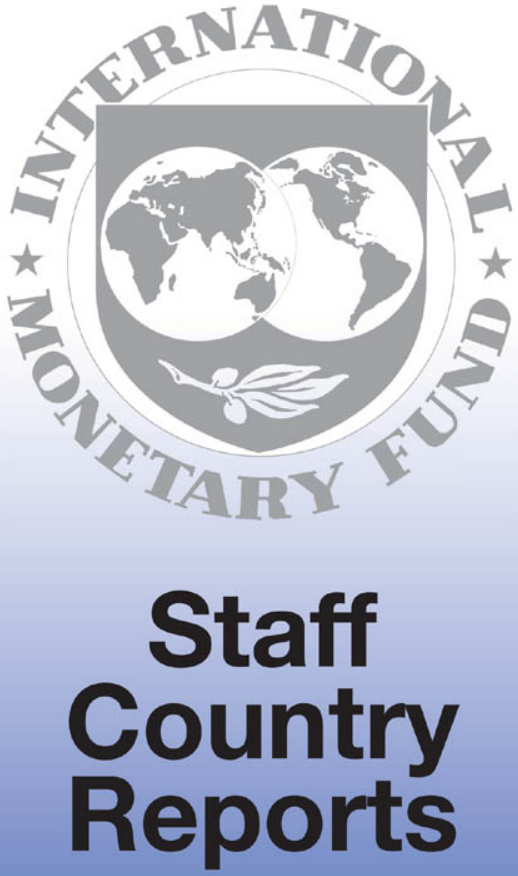


\title{
Japan: Staff Report for the 1999 Article IV Consultation
}

This report was prepared by a staff team of the International Monetary Fund following discussions with the officials of Japan on economic developments and policies. The report was then considered by the IMF's Executive Board in the context of the IMF's periodic consultation with Japan, as required under Article IV of the IMF Articles of Agreement. The views expressed in the staff report itself are those of the staff team and do not necessarily reflect the views of the Executive Board of the IMF or of the authorities of Japan; a supplementary statement by IMF staff may also be included. The views of the Executive Board as expressed in the discussion of the Article IV consultation report and as summarized in a Public Information Notice (PIN) are also included. In addition, a statement by the member country authorities may be appended. Further background documentation prepared by IMF staff for the consultation may be published separately at a later date. The policy of publication of Article IV staff reports allows for the deletion of market sensitive information.

This Article IV staff report is published-both in hard copy and on the IMF's website (http://www.imf.org)_as part of a pilot project. To assist the IMF in evaluating the pilot project for release of Article IV staff reports, reader comments on the staff report are invited prior to October 5, 2000, and may be sent by e-mail to Pilotproject@imf.org.

Copies of this report are available to the public from

International Monetary Fund • Publication Services

700 19th Street, N.W. • Washington, D.C. 20431

Telephone: (202) 623-7430 - Telefax: (202) 623-7201

Telex (RCA): 248331 IMF UR

E-mail: publications@imf.org

Internet: http://www.imf.org

Price: $\$ 15.00$ a copy

\author{
International Monetary Fund \\ Washington, D.C.
}


This page intentionally left blank

CInternational Monetary Fund. Not for Redistribution 


\title{
INTERNATIONAL MONETARY FUND
}

\author{
JAPAN \\ Staff Report for the 1999 Article IV Consultation \\ Prepared by the Staff Representatives for the \\ 1999 Consultation with Japan \\ Approved by Hubert Neiss and Leslie Lipschitz
}

July 9,1999

- This report is based on discussions held in Tokyo during May 17-28.

- The staff team met with Minister Sakaiya of the Economic Planning Agency and Governor Hayami of the BOJ; officials at the Ministries of Construction, Finance, Home Affairs, International Trade and Industry, Justice, Labor, and Posts and Telecommunication, as well as at the Bank of Japan, the Economic Planning Agency, the Financial Supervisory Agency, the Financial Reconstruction Commission, the Resolution and Collection Corporation, and the Tokyo Prefecture; and with business and financial sector representatives.

- The Managing Director visited Tokyo over May 18-19, and together with members of the staff team met with political leaders and senior officials, including Prime Minister Obuchi and Finance Minister Miyazawa.

- The staff team comprised H. Neiss (Head), C. Collyns, T. Bayoumi, J. Morsink, R. Ramaswamy, M. Mühleisen, I. Oishi (all APD), and J. Levy (RES).

- Mr. Yoshimura (Executive Director) and Mr. Takeda (Alternate Executive Director) also took part in the discussions.

- Japan has accepted the obligations of Article VIII, Sections 2, 3 and 4. The exchange regime is free of restrictions on the making of current international payments and transactions apart from those notified under Decision 144 (see Appendix I).

- Japan has subscribed to the Special Data Dissemination Standard, using a flexibility option on the timeliness of dissemination of data on general government operations.

- The principal authors of this report are Charles Collyns and Tamim Bayoumi. Supporting information and analysis are provided in two companion reports on Recent Economic and Policy Developments and Selected Issues. 


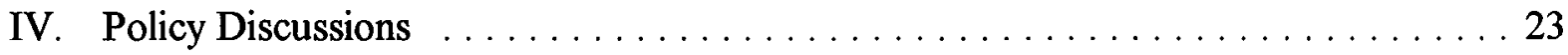

A. Fiscal Policy: Stimulus vs. Consolidation $\ldots \ldots \ldots \ldots \ldots \ldots \ldots \ldots 24$

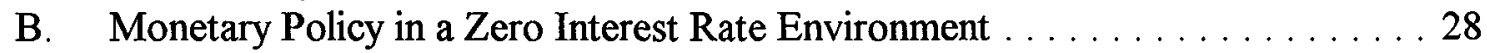

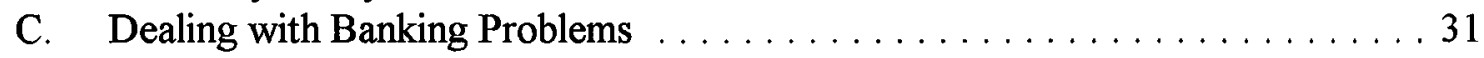

D. Financial Reforms and Corporate Restructuring $\ldots \ldots \ldots \ldots \ldots \ldots \ldots 33$

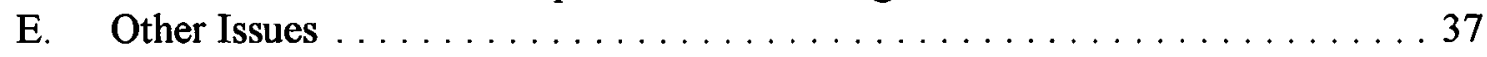

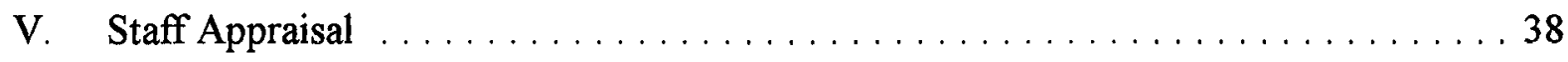

References ..............................

Boxes

1. Explaining the Collapse of Business Investment $\ldots \ldots \ldots \ldots \ldots \ldots \ldots \ldots$

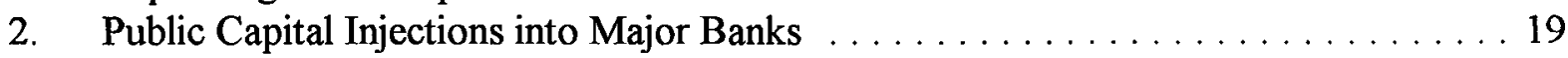

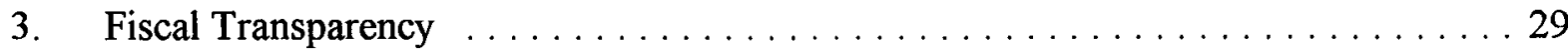

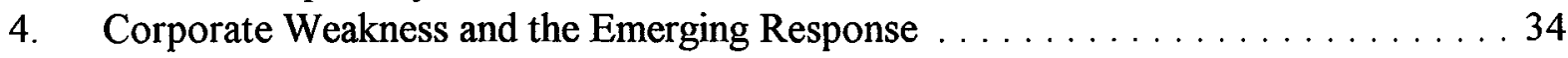

$\underline{\text { Figures }}$

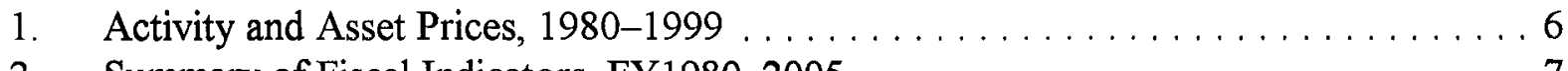

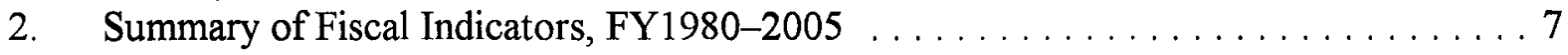

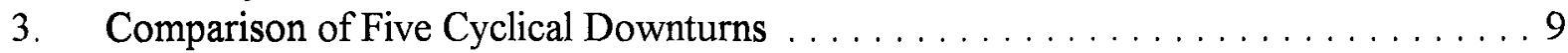

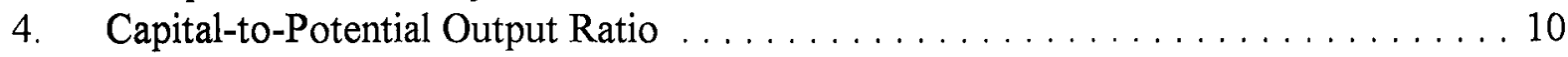

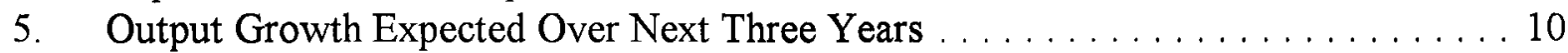

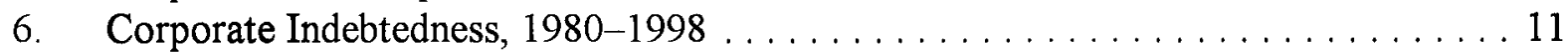

7 . Indicators of Prices and Labor Market Conditions, $1990-1999 \ldots \ldots \ldots \ldots \ldots 12$

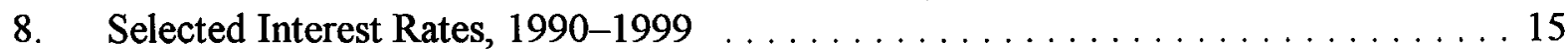

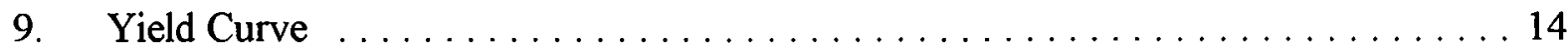

10. Exchange Rates and Interest Rate Differentials, $1998-1999 \ldots \ldots \ldots \ldots \ldots 17$

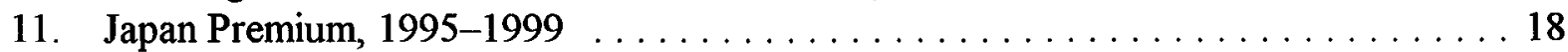

12. General Government Net Debt Excluding Social Security $\ldots \ldots \ldots \ldots \ldots \ldots 23$

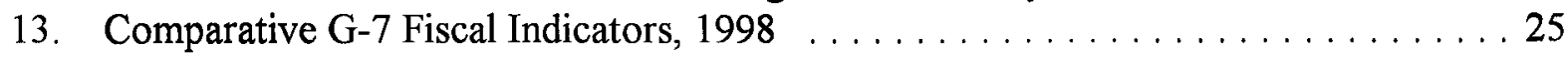

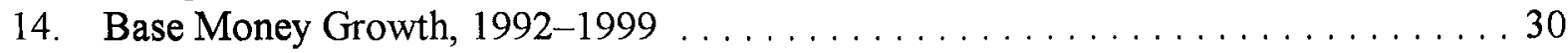


Tables

1. Selected Economic Indicators, 1992-2000 45

2. General Government Operations, $1996-1999 \ldots \ldots \ldots \ldots \ldots \ldots \ldots \ldots \ldots . \ldots 46$

3. Comparison Between Current Baseline Forecast and Low Growth Scenario . . . . . 4 47

Annexes

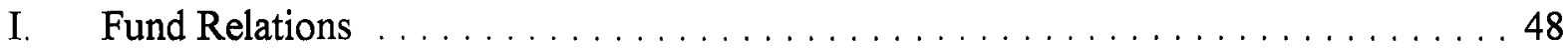

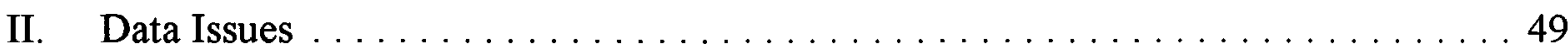




\section{INTRODUCTION}

1. Japan has endured one of the longest down-turns experienced by any major industrial country since the Second World War. The contraction that started in early 1997 was given initial impetus by a sharp swing towards fiscal consolidation, the onset of the Asia crisis, and the collapse of three major financial institutions. Responding to these developments, during the 1998 Article IV Consultation Board discussion last August, Executive Directors emphasized the need to ensure fiscal support for the economy until a recovery took hold and to take far-reaching measures to restore the Japanese financial system to health.

2. During the past year, the authorities have acted effectively to support activity and avert the risk of a systemic financial crisis, but the prospects for recovery still remain uncertain. A large dose of fiscal stimulus, reduction of short-term interest rates to their floor, and the putting in place of a comprehensive framework to deal with banking weaknesses have helped to instill an improvement in market sentiment and generate a pick-up in activity in the first quarter of 1999, after five successive quarters of output decline. However, notwithstanding the unexpectedly strong outcome for GDP in the first quarter of 1999-announced after the Article IV mission-it remains unclear if a sustained recovery has begun. The uncertainty partly reflects the inevitable difficulty in picking the turning point of an economic cycle. More fundamentally, however, the economy is likely to continue to be affected by the drag from underlying structural weaknesses, including debt and capital stock imbalances still lingering from the "bubble" period at the end of the 1980s and, more broadly, the slow adjustment of institutions and markets to challenges posed by increasingly global markets.

\section{Against this background, the 1999 Article IV Consultation discussions held in} Tokyo in May 1999 revolved around two main themes:

- How best to support activity in the short term. While the scope for additional fiscal or monetary stimulus is now nearly exhausted, resolute implementation of the present policy framework remains essential to sustaining aggregate demand. Increased transparency of both fiscal and monetary policies could help to reduce uncertainty about policy intentions, and thus enhance the impact of these policies.

- The pace and priorities for structural reforms. Further progress in tackling underlying structural problems is essential for the achievement of a sustained recovery. The discussions in this area focussed on four basic tasks: fiscal reforms that would pave the way for the substantial reduction in the general government deficit that will eventually be needed; the final resolution of banking problems and bad debts left over from the "bubble" period; the next steps for financial reforms; and the establishment of an environment conducive to corporate restructuring, including an adequate social safety net. ${ }^{1}$

\footnotetext{
${ }^{1}$ In other areas, such as regulatory reforms and trade policy, the staff has relied mainly on
} (continued...) 


\section{Recent Economic AND Policy DeVelopments}

\section{Japanese economic performance has been lackluster through most of the 1990s}

(Table 1). Since the asset price bubble burst in 1991, the economy has grown at an average of 1 percent per annum, in striking contrast to the rapid growth achieved in previous decades. Moreover, asset prices have continued to fall, with both equity and real estate in the major cities now worth less than half their values at the height of the bubble (Figure 1). While the initial downturn in activity was smaller in Japan than in other countries that experienced a correction of asset price overheating in the late 1980s - such as the United Kingdom or Sweden-the weakness in activity has been considerably more protracted.

\section{This disappointing performance has occurred despite expansionary}

macroeconomic policies. A series of fiscal stimulus packages raised the structural general government deficit by more than 6 percentage points of GDP between FY1991 and FY1998 (Figure 2 ), ${ }^{2}$ while monetary policy has been progressively eased, with the overnight call rate being reduced from more than 8 percent in 1991 to effectively zero at present. However, the fiscal multipliers seem to have been relatively small, possibly reflecting the temporary nature of many of the tax measures, the continuing lack of fiscal transparency which has made it difficult to gauge shifts in the stance of fiscal policy, and the private sector's increasing concerns about growing fiscal imbalances. Moreover, the impact of monetary stimulus has been muffled by the banking sector problems associated with falling asset prices. ${ }^{3}$

\section{After a short-lived recovery in 1996, the economy plunged back into recession in} early 1997. The downturn was initiated by a larger-than-anticipated fall in household spending after the April 1997 consumption tax hike and cuts in public investment. Further downward pressure on activity came from a reduction in domestic bank lending propelled by the desire to strengthen balance sheets in advance of the "Big Bang" financial reforms and the impending overhaul of bank regulation, as well as the disruptive impact of the failure of a major bank and two large securities firms in November 1997. Finally, the Asia crisis compounded this weakness through its impact on external demand, as well as undermining confidence more generally.

${ }^{1}$ (...continued)

analysis by the OECD and WTO secretariats.

${ }^{2}$ Japan has the smallest automatic fiscal stabilizers among the major industrial countries. Hence, part of the deterioration in the structural fiscal balance can be seen as substituting active policies for the automatic cyclical support that occurs in other countries.

${ }^{3}$ These conclusions are supported by staff work reported in Bayoumi (1999), Ramaswamy (1999), and Woo (1999), as well as the study by Posen (1999). Further analysis of the effectiveness of fiscal stimulus packages and of the monetary transmission mechanism by Mühleisen and Morsink, respectively, is provided in the 1999 Selected Issues paper. 
Figure 1

JAPAN

ACTIVITY AND ASSET PRICES, 1980-1999
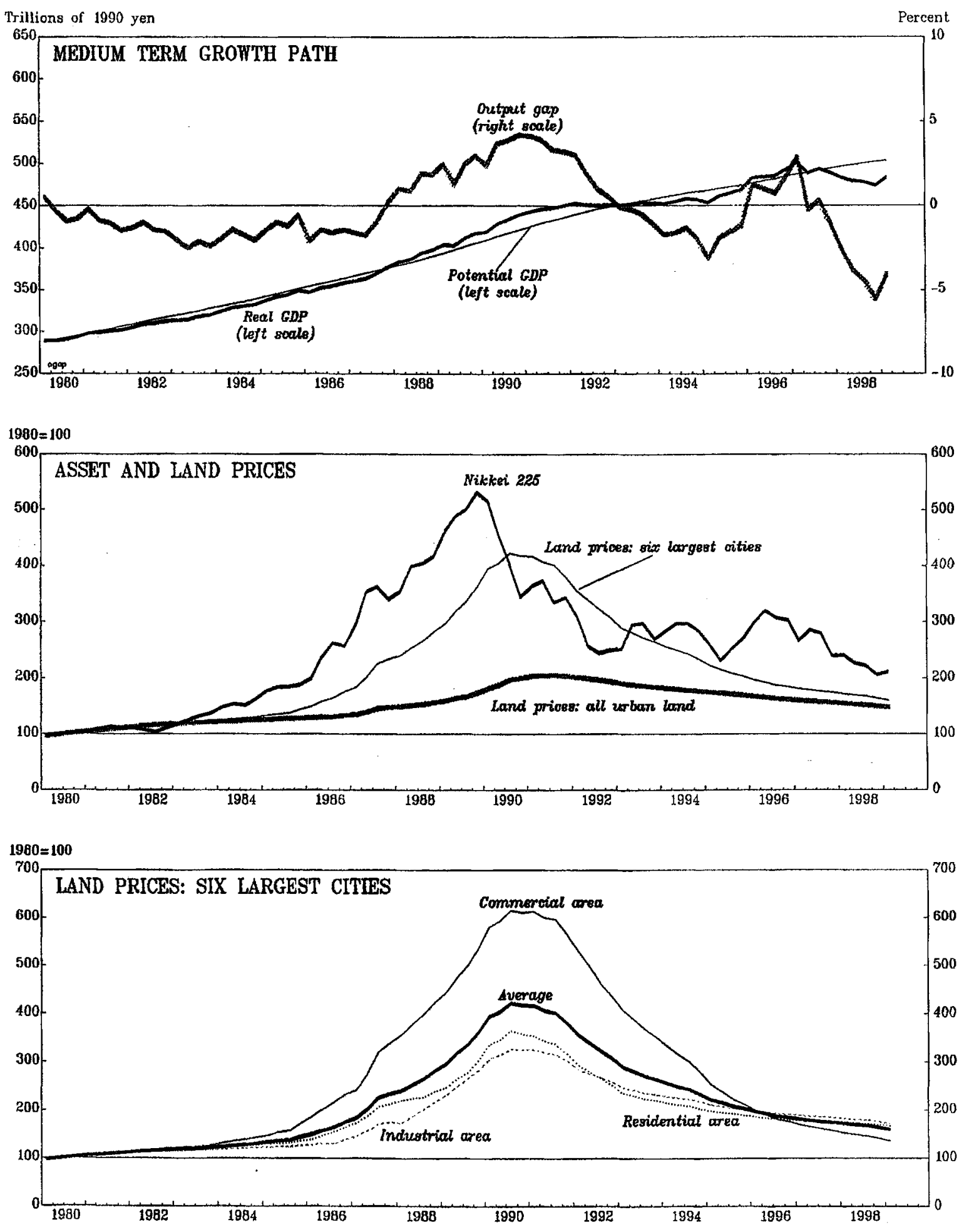

Sources: Nikkei Telecom and WEFA. 
Figure 2

JAPAN

SUMMARY OF FISCAL INDICATORS, FY 1980-2005 1/

(In percent of GDP)
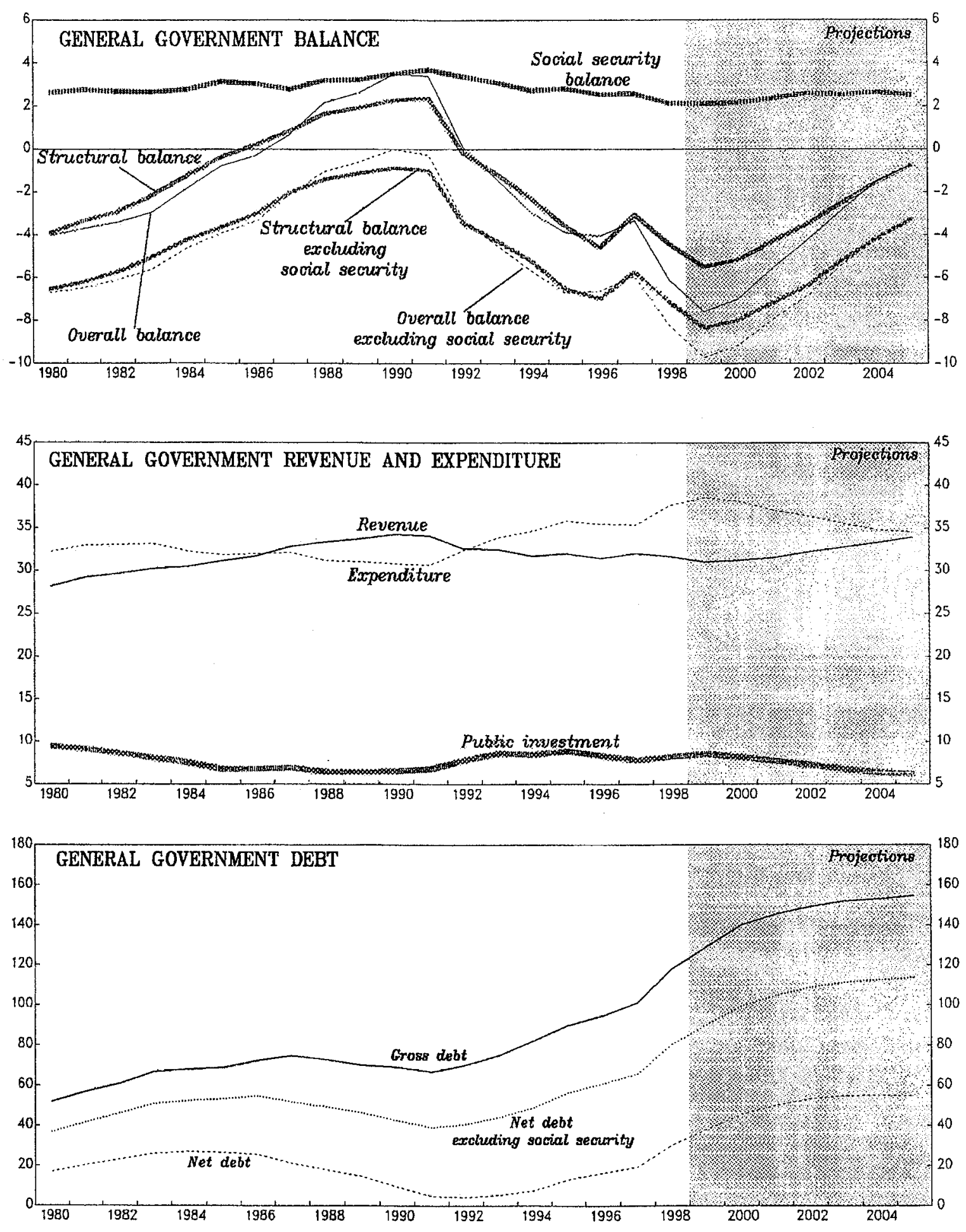

Sources: Nikkei Telecom, WEFA, and staff estimates and projections.

1/ The fiscal year is from April to March. 
7. The recession intensified in 1998, before a pick-up in activity in the first quarter of 1999. GDP declined almost 3 percent in 1998 even though the proximate causes of the initial downturn in 1997 were largely reversed. All of the main components of private domestic demand experienced far deeper and more prolonged declines than in previous recessions (Figure 3 ). However, a surge of public investment starting in the fourth quarter of 1998 , together with steps to ease financial constraints, contributed to a pick-up of private demand in the first quarter of 1999.

\begin{tabular}{|c|c|c|c|c|c|c|c|}
\hline \multicolumn{8}{|c|}{$\begin{array}{c}\text { Japan: GDP Growth } \\
\text { (Percent change from previous period) }\end{array}$} \\
\hline & \multirow[t]{2}{*}{1996} & \multirow[t]{2}{*}{1997} & \multirow[t]{2}{*}{1998} & \multicolumn{3}{|c|}{1998} & \multirow{2}{*}{$\begin{array}{r}1999 \\
\text { Q1 }\end{array}$} \\
\hline & & & & Q2 & Q3 & Q4 & \\
\hline GDP & 5.0 & 1.4 & -2.8 & -0.7 & -0.3 & -0.8 & 1.9 \\
\hline $\begin{array}{l}\text { Domestic demand } \\
\text { Of which: }\end{array}$ & 5.7 & 0.1 & -3.5 & -1.2 & -0.6 & -0.5 & 2.2 \\
\hline Private consumption & 2.9 & 1.0 & -1.1 & -0.1 & -0.1 & -0.2 & 1.2 \\
\hline Public investment & 9.2 & -10.4 & -0.3 & -3.0 & 3.7 & 10.6 & 10.3 \\
\hline Business investment & 11.3 & 7.1 & -11.3 & -4.8 & -2.7 & -5.5 & 2.5 \\
\hline Net exports (contribution) & -0.5 & 1.4 & 0.6 & 0.4 & 0.3 & -0.4 & -0.2 \\
\hline
\end{tabular}

8. The drop of business investment over the past two years has been particularly severe. By the fourth quarter of 1998, business investment was almost 20 percent below its early 1997 peak, a contraction far sharper than in previous recessions. Cutbacks in investment have now lowered the annual growth of the capital stock to less than 2 percent, compared to over 8 percent at the peak of the bubble. To an important extent, the abrupt decline has reflected continued efforts to address excess indebtedness and over-investment inherited from the "bubble" period (Box 1). More generally, an increasing focus on profitability rather than market share and reduced expectations of long-term growth encouraged firms to cut back plans for capital accumulation in the context of broader programs for corporate restructuring. Limits on the availability of bank credit also seem to have been a negative factor, particularly for small and medium enterprises (SMEs), although recently this constraint has been alleviated by policy actions, contributing to an investment turn-around in the first quarter of 1999 .

9. Private consumption has been dampened by falling incomes and concerns about labor market adjustment. Monthly earnings have declined about 3 percent over the past year as bonus payments and overtime have been curtailed (Figure 7). Even with tax cuts, disposable income has declined about $1 \frac{1}{2}$ percent. Moreover, expectations of future earnings have been undermined by a sharp rise in the unemployment rate over the past year and by prospects for further increases in the period ahead as a number of major corporations have 
Figure 3

JAPAN

COMPARISON OF FIVE CYCLICAL DOWNTURNS

Index (peak=100)
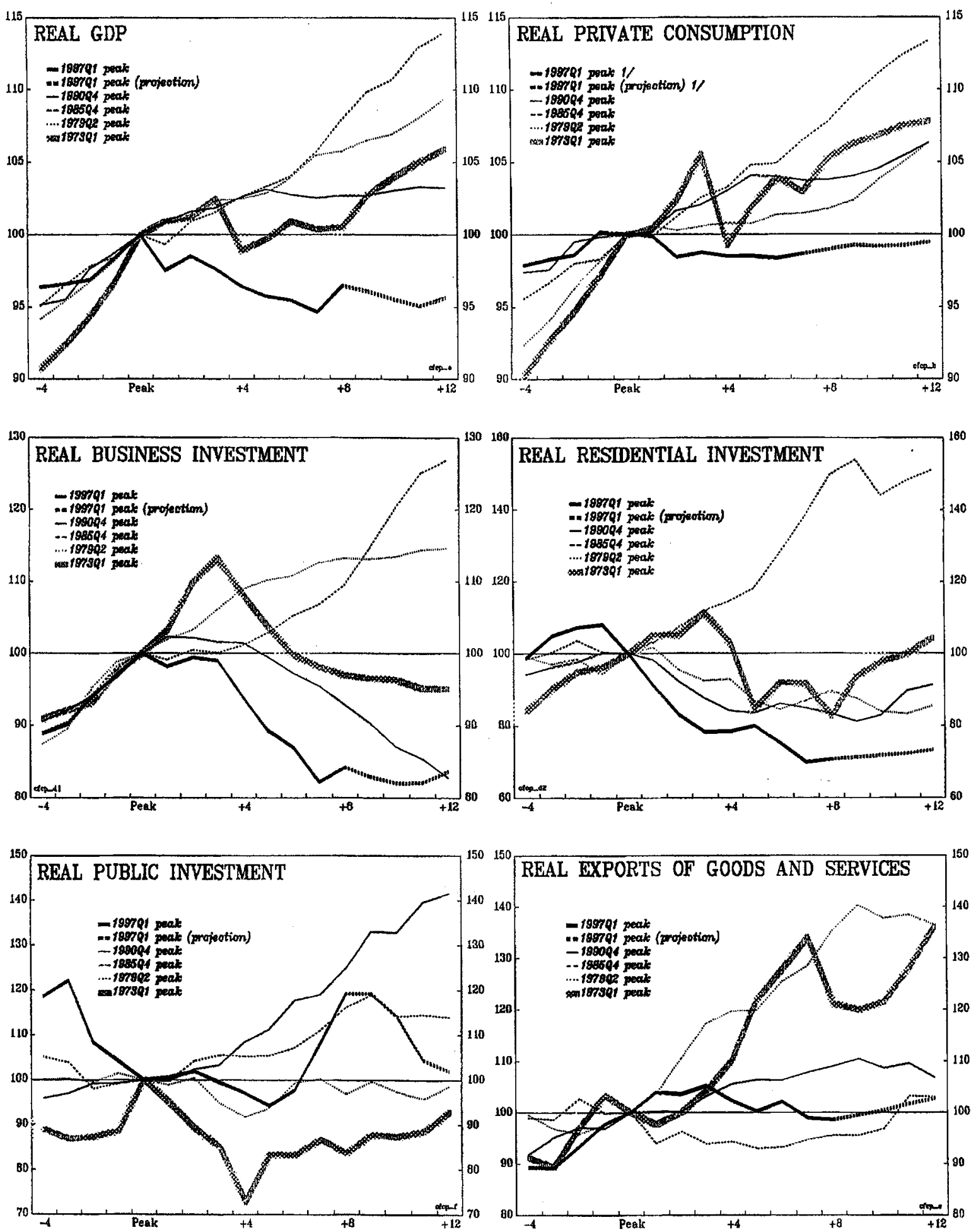

Source: Nikkei Telecom.

1/ Three quarter moving averages (centered). 


\section{Box 1. Explaining the Collapse of Business Investment ${ }^{1}$}

The steep decline in private investment since early 1997 has been driven in part by cyclical factors and credit constraints. Corporate profits have fallen sharply over the last two years, reflecting the slowdown in business activity. Moreover, as discussed in more detail in the 1998 Selected Issues paper, banking sector strains contributed to a "credit crunch" affecting particularly small and medium enterprises, which did not have access to securities markets and had relied heavily on land collateral to back bank borrowing. However, these factors alone cannot explain the severity of the current downturn compared to earlier investment cycles.

The depth and duration of the decline in private investment reflects continued stock adjustment to the excess capital created during the asset price bubble. The ratio of net business capital to potential GDP rose sharply in relation to trend between 1986-91 (Figure 4), fueled by a blend of exuberant expectations of sustained growth and easy access to finance. When the bubble burst in 1990, the economy slowed sharply, saddling the economy with substantial excess capacity and high levels of debt. Despite the significant decline in private investment over 1991-94, staff estimates suggest that the ratio of net business capital stock to potential GDP was not restored back to the earlier trend.

Recent weakness in business investment probably also reflects a longer term structural reduction in the demand for capital accumulation. With Japan's "catch-up" phase of economic development essentially over, and the labor force now declining, medium-term growth expectations have been pruned drastically (Figure 5). Moreover, it is increasingly apparent that, in a world of capital mobility and rapidly industrializing competitors, Japanese industry will need to refocus on raising productivity and profitability, rather than maximizing market share - a shift that would suggest that the past trend rise in capital-output ratio will not be sustained.

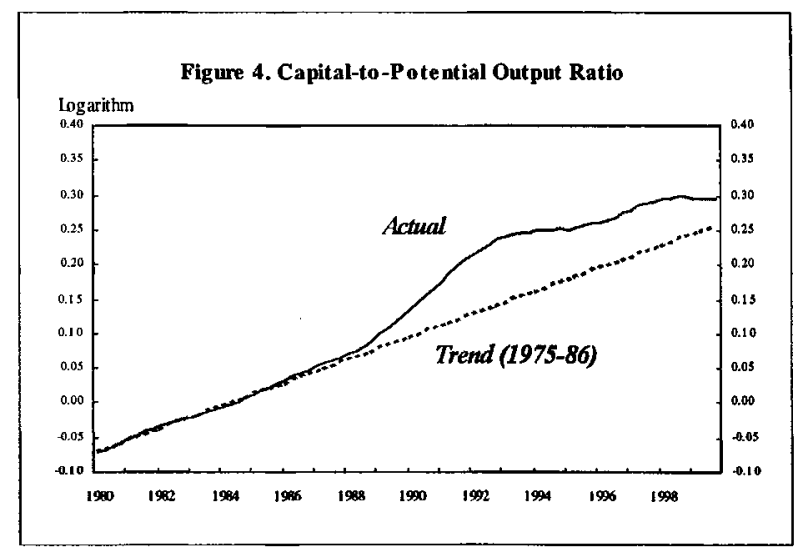

Econometric work by the staff supports the view that debt and the capital stock overhang have been critical in explaining the current weaknesses in private investment. Estimation of an aggregate investment function indicates that the debt burden and the lagged capital-output ratio are the most robust explanatory variables for trends in private investment. Tobin's $Q$ was also identified as a significant explanatory variable.

Disaggregated analysis reveals interesting differences across three broad sectors. The collapse of investment in the "bubble sectors" - i.e., primarily the construction and real estate sectors - appears to be related in large part to the excessive debt built up in the bubble period. By contrast, balance sheets in the manufacturing sector-which is more exposed to international competition-have strengthened significantly (Figure 6). The steep decline in investment in this sector in the 1990s appears to be influenced more by the capital stock overhang and declining growth expectations. Investment in manufacturing also appears more responsive to changes in the cost of capital. The rate of investment in the "infrastructure sectors"-i.e., primarily transportation and communication as well as electricity - actually rose in the mid-1990s, reflecting a robust response to deregulation initiatives during this period.

${ }^{1}$ This box draws mainly on Ramaswamy in the 1999 Selected Issues paper. 
FIGURE 6

JAPAN

CORPORATE INDEBTEDNESS, 1980-1998
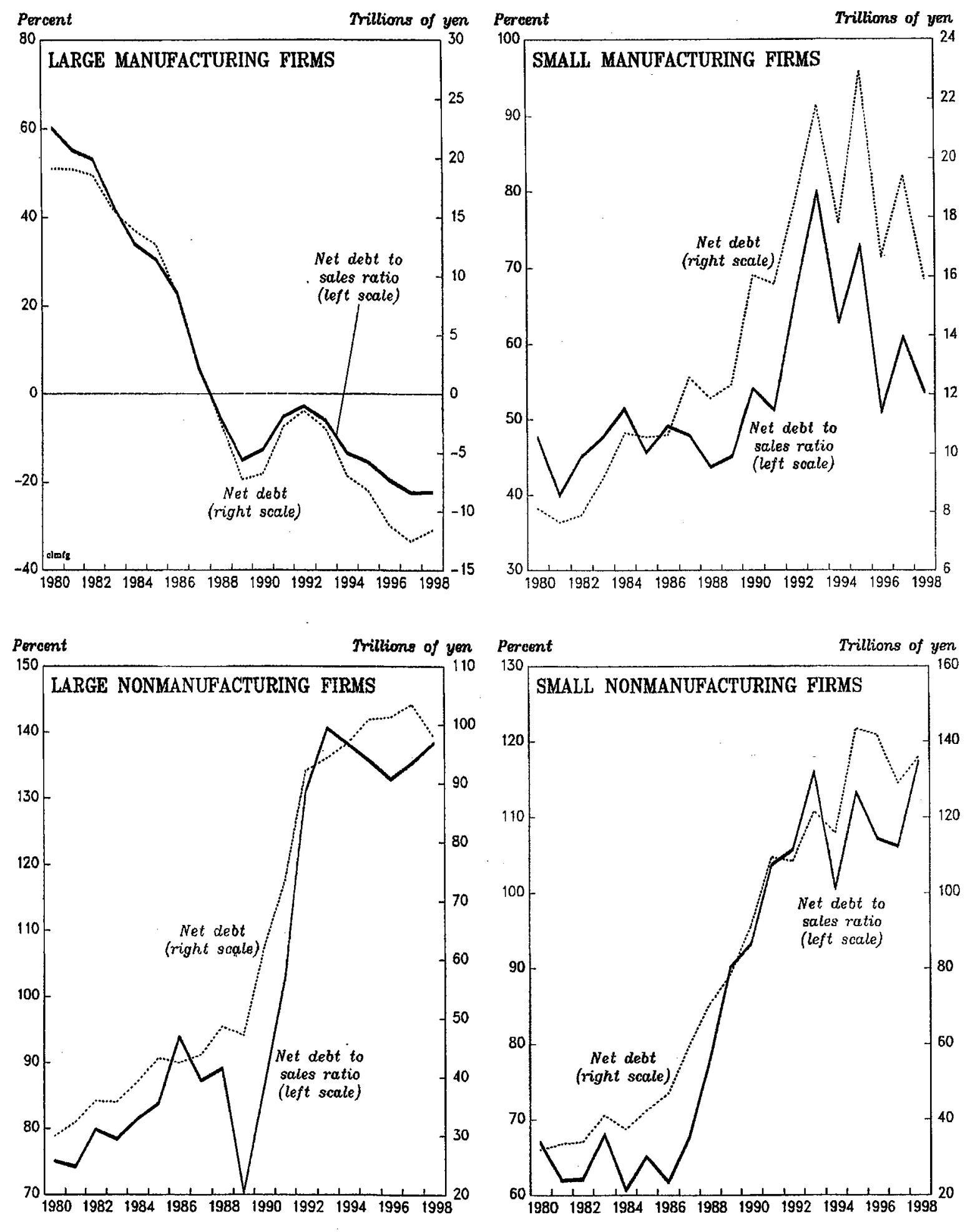
Source; Bank of Japan. 
Figure 7

JAPAN

INDICATORS OF PRICES AND LABOR MARKET CONDITIONS, 1990-1999 1/
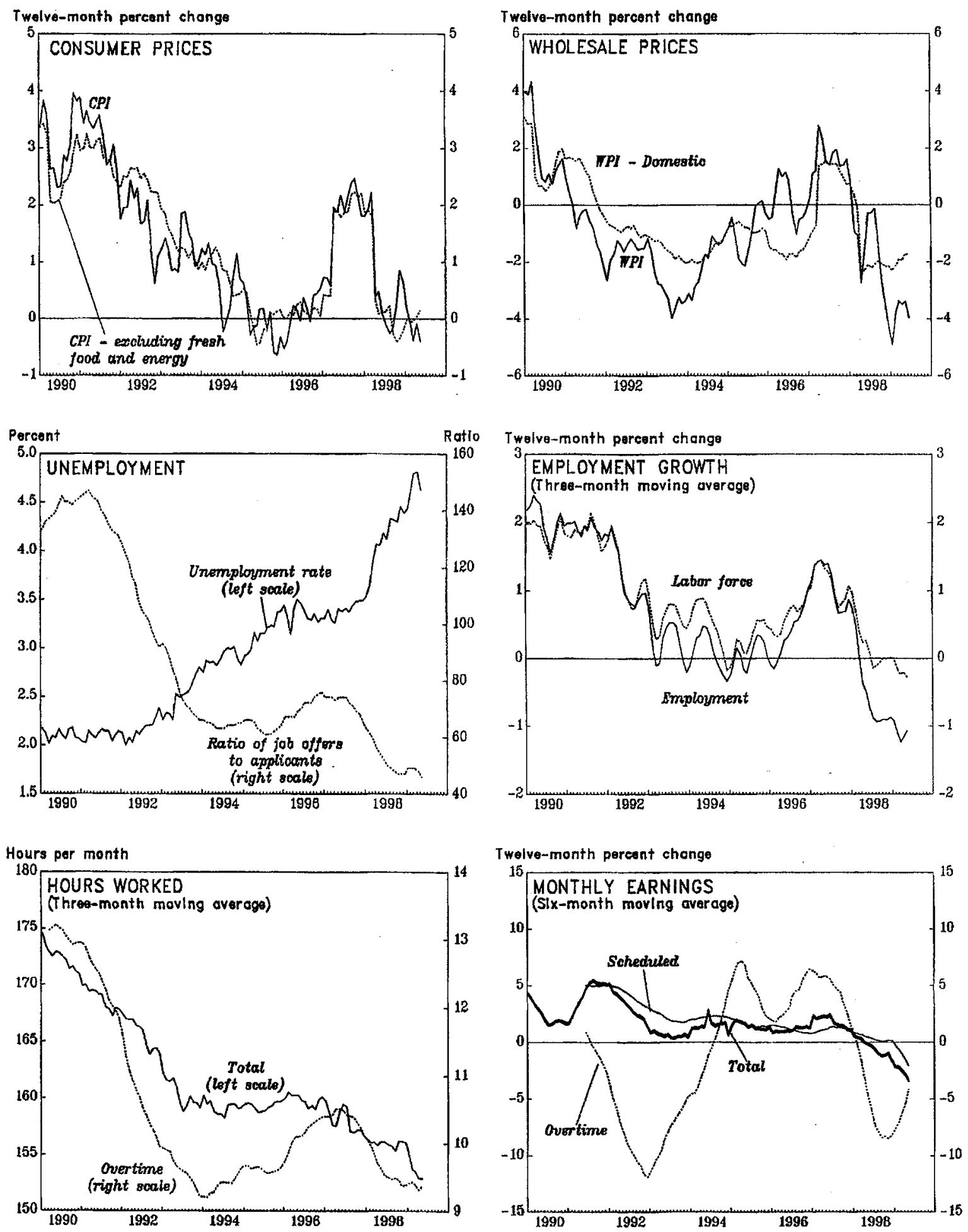

Source: Nikkei relecom and WEFA.

1/ Seosonally adjusted data. 
announced employment reduction plans as part of restructuring efforts. Labor market weakness is also demonstrated by the fall in the ratio of job offers to job seekers to a record low in May 1999. Against this, the receding threat of financial crisis has been a positive influence on consumer sentiment, which may partly explain a modest pick-up in spending in the first quarter of 1999.

10. Support from external demand has receded. Export volumes declined through 1998 and into the first quarter of 1999 , as the boost to exports coming from earlier yen depreciation waned. Moreover, concerns about protectionist pressures abroad may have undercut export growth in some sectors, such as steel. Real imports also fell through 1998, mainly reflecting weak domestic demand. The current account surplus rose 1 percentage point of GDP to $31 / 4$ percent of GDP in 1998, boosted by declining oil prices and the J-curve effect from yen appreciation in the second half of the year.

11. Deflationary pressures have so far been limited. Excluding the impact of imported goods prices, the 12-month rate of decline of the domestic WPI has been about 2 percent, not much lower than the average rate of decline during the 1990s. The 12-month change in the core CPI (excluding fresh food and energy) has been close to zero in recent months (see Figure 7). Possible explanations for why deflation has so far not intensified-despite an output gap estimated at around 4 percent of GDP in 1998 and at least a degree of downward flexibility in labor compensation - include the lack of competition in certain domestic markets, particularly for services, and slow adjustment of price expectations to deflationary conditions. ${ }^{4}$

\section{Responding to increasing evidence of weak activity, the authorities have acted to} inject substantial fiscal stimulus. A $¥ 16.7$ trillion (3 percent of GDP) package of public works and temporary income tax cuts in April 1998 was followed by a $¥ 24$ trillion (5 percent of GDP) package in November, including permanent cuts in personal and corporate income tax rates, increased credit guarantees for bank loans to SMEs, temporary consumption vouchers, and a further boost to public works spending. ${ }^{5}$ The FY1999 budget confirmed the expansionary overall fiscal stance, and included additional tax incentives aimed at boosting residential investment and investment in information technology. A further $¥ 500$ billion package of measures to support employment creation and retraining was announced in June

\footnotetext{
${ }^{4}$ Shiratsuka (1999) has estimated that measurement bias in the consumer price index overstates price inflation by about 1 percent per annum. To the extent that price discounting not captured by price surveys has increased, this bias may have risen.

${ }^{5}$ As discussed by Mühleisen in the 1999 Selected Issues Paper, the actual fiscal impact of these packages has typically been considerably less than the headline amounts in recent years. This experience has reflected a variety of factors, including the fact that new measures have often replaced temporary measures introduced in the previous year, and the inclusion in the packages of measures to increase the availability of credit from government financial institutions funded through the Fiscal Investment Loan Program (FILP).
} 
1999, and additional tax incentives to support corporate restructuring are also expected to be submitted to the current Diet session. The staff estimates that, together, these measures imply a fiscal stimulus of around 1 percentage points of GDP in FY1999, somewhat smaller than the stimulus in FY1998. However, it should be emphasized that, in view of the limited information available on a consolidated basis, such estimates are subject to considerable uncertainty. ${ }^{6}$

\begin{tabular}{|lcccc|}
\hline \multicolumn{4}{c|}{ Japan-General Government Deficit } \\
(In percent of GDP) & \\
\hline & FY 1996 & FY 1997 & FY 1998 \\
Est. & $\begin{array}{c}\text { FY 1999 } \\
\text { Proj. }\end{array}$ \\
\hline General government deficit & 4.1 & 3.4 & 6.1 & 7.4 \\
Excluding social security & 6.6 & 5.9 & 8.3 & 9.5 \\
Fiscal impulse (= change in structural & 1.0 & -1.6 & 1.3 & 1.0 \\
deficit including social security) & & & & \\
\hline Source: Table 2. & & & & \\
\hline
\end{tabular}

13. The Bank of Japan (BOJ) has continued to ease monetary conditions over the past year by cutting interest rates and supporting credit intermediation, while other government financial institutions have also been mobilized to relax financing constraints:

- Having already lowered the target rate in the overnight call market from slightly under 0.5 percent to 0.25 percent in September 1998, the BOJ eased policy further starting in February 1999, and by March the overnight rate had been reduced effectively to zero (Figures 8 and 9). In April, the Governor announced that this "zero rate policy" would be sustained until deflationary concerns were dispelled. This policy, together with indications that public pension and life insurance funds would continue to be invested in long-term

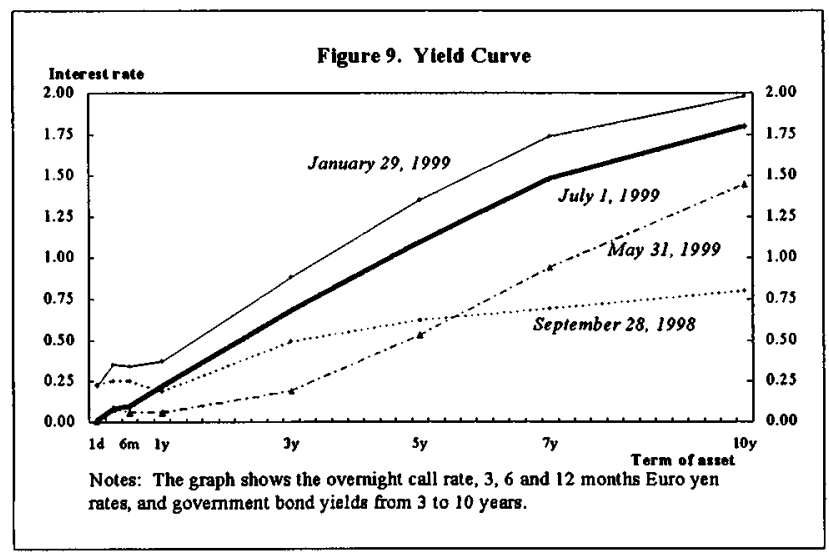

${ }^{6}$ The staff estimates are derived by adjusting the authorities' budget estimates to reflect (i) the likely timing of spending on public works and (ii) the assumption that local governments largely offset their share in jointly financed projects in stimulus packages by cuts in ownaccount expenditure. 
Figure 8

JAPAN

SELECTED INTEREST RATES, 1990-1999
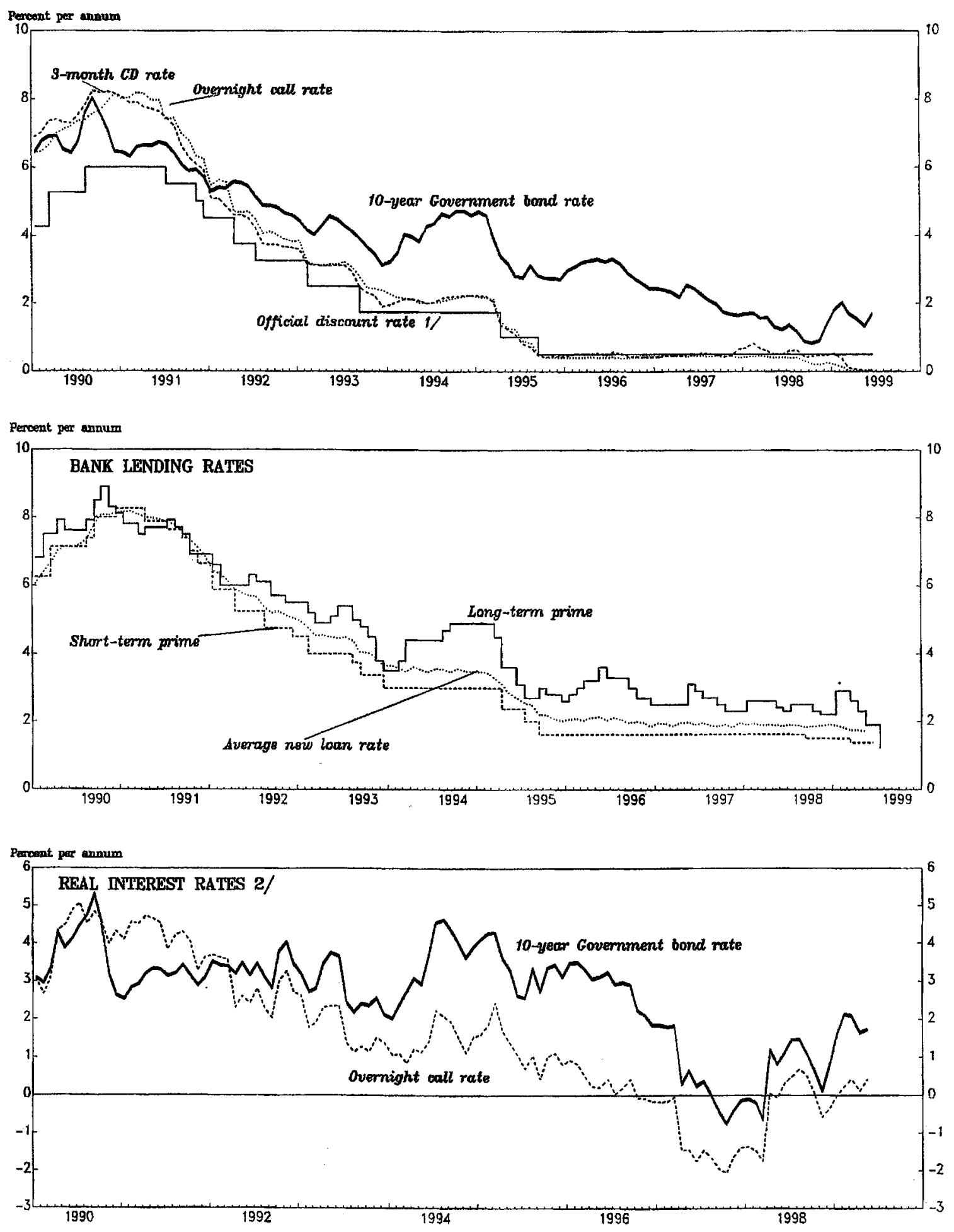

Sources: Nikkei Telecom; and WEFA.

1/ End of period.

2) Nominal rotes minus year on year CPI inflation. 
government bonds, helped to reverse a surge in long-term bond yields that had occurred from December 1998 as markets responded to a combination of fiscal stimulus initiatives and concerns about the declining capacity of the public sector to absorb government paper. Interest rates have tended to rise, however, since late May, partly in response to improving sentiment about economic prospects and speculation that the "zero rate policy" would be reversed sooner than previously expected.

- $\quad$ Stepped-up BOJ participation in commercial paper (CP) repo operations has been used to facilitate corporate financing. Moreover, the scope of $\mathrm{CP}$ repo operations has been extended to longer maturities, and new BOJ facilities were put in place to support bank lending in the second half of FY1998 and to purchase bank bills collateralized by commercial bonds and loans on deeds.

- $\quad$ Public funds have been provided to increase the availability of loan guarantees from local government credit guarantee associations by $¥ 20$ trillion. ${ }^{7}$ Of this, $¥ 14$ trillion had been used by end-March 1999, helping to stabilize lending by regional banks to small firms and contributing to a sharp reduction in the number of bankruptcies.

\section{Exchange rate policy has been geared to resisting movements in the yen to} extreme levels and avoiding unstable market conditions. The authorities intervened to support the yen after it fell to a low level in June 1998 (Figure 10). Subsequently, the yen reversed course, and reached $¥ 109$ per dollar in early January 1999 . The appreciation during September and October 1998 occurred in the context of turbulent global market conditions which prompted an easing of U.S. monetary policy and an unwinding of yen carry trade positions, while the continued rise of the yen through early 1999 seems to have reflected in part the jump in long-term government bond rates in Japan and market perceptions that the authorities were not displeased with the strengthening of the currency. After February 1999, the further easing of monetary policy, together with expressions of official concern that an excessively strong yen would be undesirable, encouraged the yen to return to around $¥ 120$ per dollar. In mid-June, the announcement of an unexpectedly strong rise in output in the first quarter led to renewed upward pressure on the yen, but this pressure was effectively countered by exchange market intervention.

\section{A framework for dealing with banking problems has now largely been put in place, reducing immediate concerns for systemic risk and shifting attention to implementation issues:}

\footnotetext{
${ }^{7}$ The authorities have pledged $¥ 1$ trillion of additional funds as needed to help cover possible losses associated with such guarantees.
} 
EXCHANGE RATES AND INTEREST RATE DIFFERENTIALS, 1990-1999
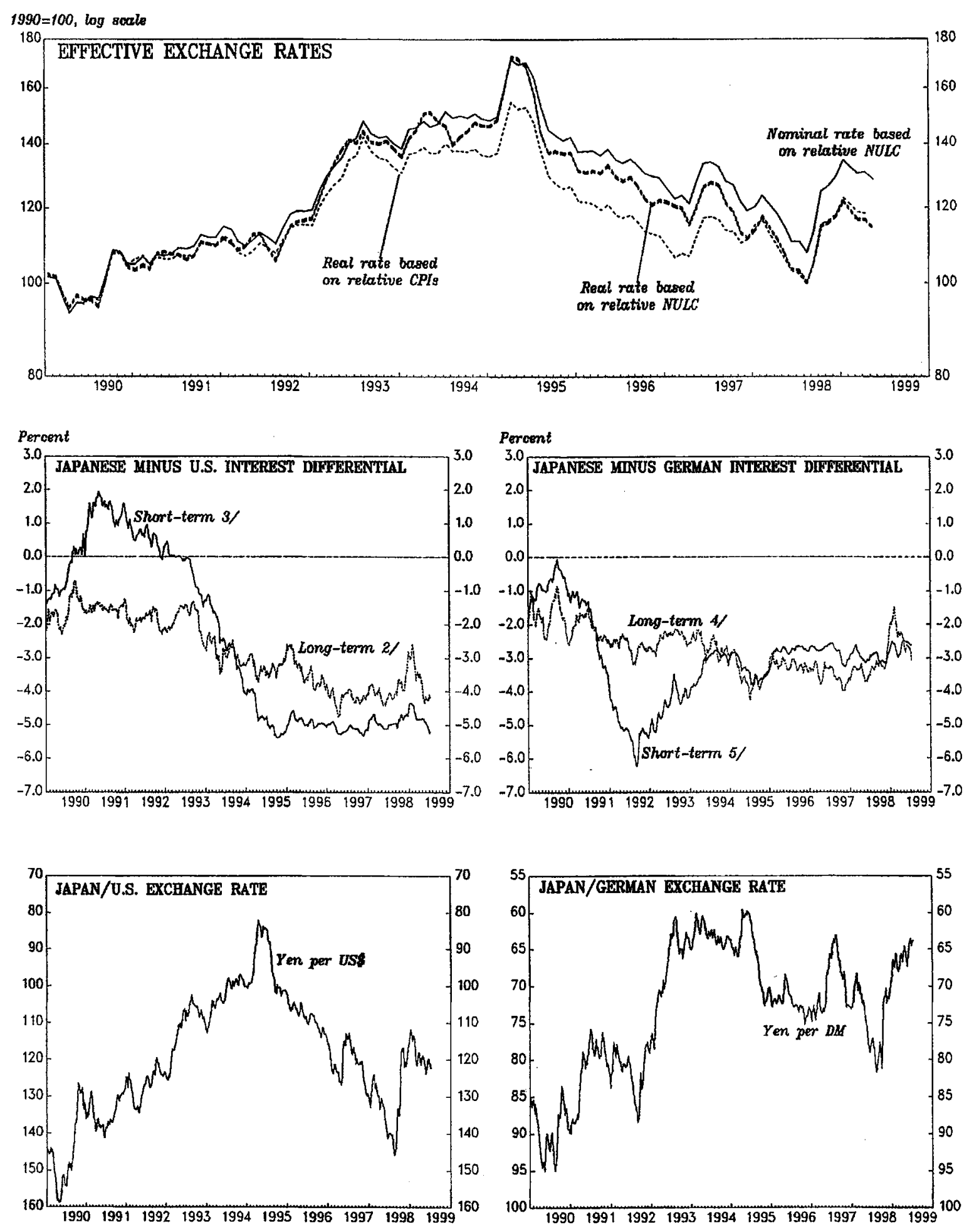

Sources: IMF, Information Notice System; and Nikkei Telecom.

1/ Based on IMF NULC rote.

2/ Japan: ten-year government bond rate; United States: ten-year government bond rate.

3/ Japan: three-month CD rate; United States: three-month CD rote.

4/ Japan: ten-year government bond rote; Germany: ten-year government bond rate.

5/ Japan: three-month CO rate; Germany: three-month Interbank rate. 
- In October 1998, the government set aside $¥ 60$ trillion (12 percent of GDP) for financial support for banks, including $¥ 25$ trillion for capital injections, $¥ 18$ trillion mainly for funding operations of nationalized banks, and $¥ 17$ trillion for protection of depositors of failed institutions. 15 major banks have received $¥ 7.5$ trillion in capital injections, based on detailed restructuring plans (Box 2). Together with the BOJ's actions to ensure ample liquidity, these steps have helped to reduce concerns about bank failures, and the "Japan premium" was virtually eliminated by March 1999 (Figure 11). However, as discussed in Box 2, banking analysts still question whether the planned changes to bank operations go far enough to boost

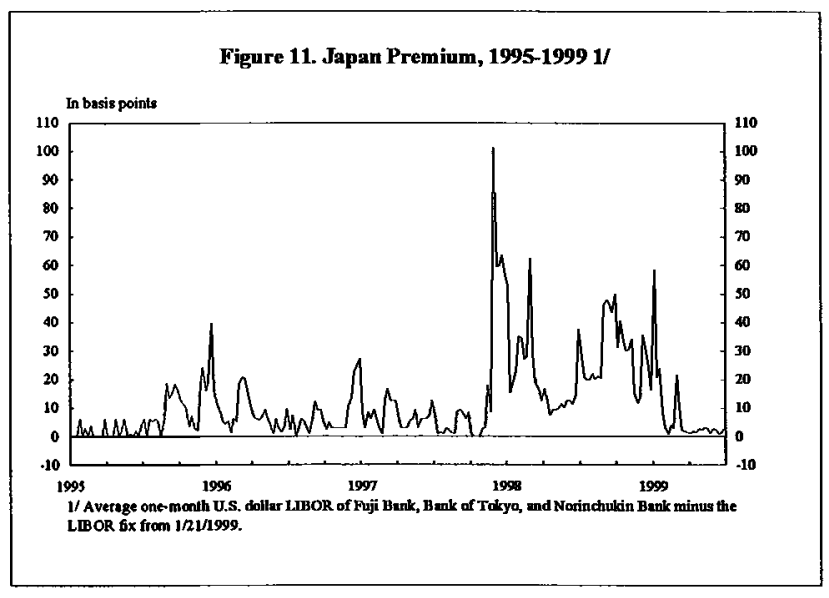
bank profitability to international levels.

- The newly-created Financial Supervisory Agency (FSA) has effectively increased regulatory pressure on banks to provision against bad loans, including through special audits and the introduction of a new inspection manual, which should help to ensure more uniform application of loans classification and provisioning criteria. However, it is still unlikely that the full extent of the deterioration of bank balance sheets has been recognized. ${ }^{8}$

- The authorities have been proactive in applying the new framework for dealing with failed institutions, including through the nationalization of the Nippon Credit Bank in late 1998 and, more recently, the placing of three second-tier regional banks under government administration. By contrast, the timing of earlier bank failures-including nationalization of the Long Term Credit Bank in October 1998-was typically driven by market forces. However, none of the banks falling under public control has yet to be restored to the private sector.

\footnotetext{
${ }^{8}$ As discussed by Morsink in the 1999 Economic and Policy Developments paper, uncovered loan losses for all banks are estimated at around $¥ 15$ trillion ( 3 percent of GDP) as of endSeptember 1998. Since then, banks have set aside substantial additional provisions. However, against this, future loan losses are likely to be under-estimated to the extent that new bad loans from the current recession have not been fully taken into account.
} 


\section{Box 2. Public Capital Injections into Major Banks ${ }^{1}$}

Under legislation passed in October 1998, the Financial Reconstruction Commission (FRC) provided capital injections of $¥ 7.5$ trillion (1 $1 \frac{2}{2}$ percent of GDP) at end-March 1999, about four times the amount injected in March 1998 under the old recapitalization scheme. ${ }^{1}$ In contrast to last year, the bulk of the public funds were structured as convertible preferred stock, which - in principle - will give the authorities considerable leverage over banks that fail to perform. If the government converts its entire holdings of preferred stock into common stock at current market prices, it would gain majority stakes in four major banks. The government could exercise its right to convert stock at these four banks as early as July 1999; conversion dates are longer - up to seven years - for stronger banks.

The receiving banks were largely those that received public money the last time-the main exception being the Bank of Tokyo-Mitsubishi, which decided not to apply. Banks had to meet two criteria to qualify for public funds: positive net worth and ability to generate long-term profits. In determining net worth, the FRC applied somewhat stricter provisioning standards, including higher ratios against Class 3 (doubtful) loans and the substandard section of Class 2 (special mention) loans. Major banks made provisions of about $¥ 10$ trillion in FY1998, about $¥ 3$ trillion more than projected in November 1998 .

To show long-term profitability, receiving banks submitted detailed restructuring plans. These had four main components:

- Expansion of profitable activities. Gross incomes are to be raised on average by about 3 percent over four years, through increasing housing loans and loans to small enterprises, offering private banking services to wealthy clients, and selling investment trusts (mutual funds). While such efforts deserve priority, as Japanese banks have relatively low revenues compared to other internationally-active banks, profit margins in these activities are likely to fall. There is also the danger that banks will expand highmargin but risky activities, such as derivatives trading.

Cost-cutting. Plans call for cutting both personnel costs and the number of domestic branches on average by 12 percent over four years. The number of overseas branches is expected to be cut back sharply, although all but one of the banks plan to remain internationally active. Some observers have argued that cost-cutting is likely to be counter-productive, as Japanese banks already have low costs compared to other international banks and need to spend more on information technology.

Strategic alliances. Trust banks have been especially active in announcing merger plans. However, these are largely defensive alliances, and their overall impact on excess capacity is likely to be limited.

Balance sheet strengthening. Receiving banks have supplemented public capital injections by raising an additional $¥ 2$ trillion of capital from private sources, largely from members of the same industrial group. Banks are also planning to increase package sales of distressed loans and to sell cross shareholdings.

While the public capital injections into major banks have stabilized the banking system, they are also perpetuating excess capacity. Banks' restructuring plans appear unlikely to restore core profitability, because, in the absence of more thorough-going consolidation, efforts to boost revenues are too modest (Atkinson 1999). Moreover, competition from the government-backed postal savings system remains strong.

${ }^{1}$ This box draws on Morsink in the 1999 Selected Issues paper. 
- $\quad$ Recent steps to encourage the resolution of problem loans include: (i) the creation of a new Resolution and Collection Corporation (RCC) from two earlier loan disposal agencies, with expanded powers to acquire bad loans from solvent as well as failed banks; (ii) legislation to facilitate setting up special purpose vehicles for securitizing loans backed by real estate; and (iii) allowing tax deductibility of debt forgiveness in the context of comprehensive restructuring agreements.

16. Over the past year, structural reforms have mainly focussed on the financial sector and changes to promote corporate restructuring:

- The "Big Bang" financial reforms remain on schedule and are now near completion. Recent changes include allowing banks to sell mutual funds, establishing investor protection schemes for the life insurance and securities industries, the abolition of the securities transaction tax, exempting nonresidents from withholding taxes on government securities, and market pricing of short-term government financial bills. A further round of measures is scheduled for October 1999, including full liberalization of brokerage commissions, allowing commercial bank subsidiaries to deal in shares, and allowing banks to issue long-term debt.

- The "Big Bang" reforms are being complemented by the progressive introduction of improved accounting standards, including consolidated financial accounting and marking to market, to be completed by FY 2002.

- New legislation is being prepared to introduce a more workable bankruptcy code for corporate rehabilitation and is expected to be presented to the Diet in September.

- The June 11 jobs package included a number of measures to facilitate corporate restructuring, including liberalization of limits on bank ownership to facilitate debtequity swaps and easing the Anti-Monopoly Law to allow large-scale mergers (after consideration of international competition). Tax changes to support restructuring that are expected to be submitted to the current Diet session include: extending the period for carrying forward losses from scrapping capital equipment from 5 to 7 years; cuts in registration and licensing fees for creation of new companies as spin-offs; and accelerated depreciation on new investment to replace old facilities.

- $\quad$ Elsewhere, progress with structural reform has been slower and more piece-meal. The Deregulation Committee developed last year a three-year deregulation plan for FY1998-FY2000 covering 634 items. The progress report published in late March includes an additional 292 measures, including steps to liberalize job placement services. Progress has also been made toward finalizing the government's administrative reform program, aimed at streamlining the structure of government. 


\section{ECONOMIC OUTLOOK}

\section{The staff's baseline GDP forecast has now been marked up to $1 / 4$ percent growth} in 1999 and 1 percent growth in 2000 , a substantially stronger outlook than incorporated in the Spring WEO exercise. ${ }^{9}$ The upward revisions largely reflects the unexpectedly strong first quarter GDP out-turn and increasing signs of a return of business confidence. However, the monthly indicators of activity through April-May have been mixed, supporting the view shared by both market and government observers that the underlying trend of private demand remains flat at best. Indeed, there could well be further output declines in the latter part of 1999 as the impulse from public investment recedes, although growth should gather momentum in 2000 , assuming that the general government structural deficit is broadly maintained. Looking at the components:

- $\quad$ Corporate surveys indicate that business investment is likely to decline significantly in 1999 overall as firms continue to adjust to past over-investment, although the relaxation of credit constraints facing SMEs may help these firms at least in the short term. ${ }^{10}$ By 2000 , a rebound in corporate profitability should help to underpin a broader investment recovery.

- Household spending is likely to continue to be dampened by weak compensation growth and continuing concerns about employment prospects, although residential investment has benefitted from new tax incentives and expectation of rising long-term interest rates. The unemployment rate is projected to continue to rise, reaching $5 \frac{1}{2}$ percent in 2000 .

- $\quad$ Net exports would make a small negative contribution in 1999 as export volume growth has been affected by the strengthening of the yen in the second half of 1998 . Nevertheless, with weak commodity prices helping the terms of trade, the current account surplus would rise to around $3 \frac{1}{2}$ percent of GDP.

18. Deflationary pressures seem for now to be in check. Yen depreciation and rising oil prices in recent months have tended to raise import costs, while the recent easing of monetary policy and pick-up in activity have helped to support price expectations. Nevertheless, BOJ

\footnotetext{
${ }^{9}$ The official forecast is for 0.5 percent growth in FY1999. The latest private consensus forecast is for a 0.8 percent decline in output in 1999 , but this is still largely based on projections prepared prior to release of first quarter GDP data.

${ }^{10}$ While an early resolution to banking sector problems remains a key to achieving a sustained recovery, this is unlikely by itself to generate significant momentum in the short term-the experience with banking sector reform in other countries is that a recovery catalyzes bank lending, not the other way around.
} 
officials emphasized that the situation needed to be monitored closely and remained concerned that deflationary forces could intensify later in the year if the economy weakened.

19. The short-term outlook remains subject to considerable uncertainty. On the upside, once a sustained recovery in private demand does get under way, the rebound could be quite strong as restored confidence feeds on itself. Nevertheless, there are also considerable downside risks, and the moderate recovery envisaged cannot be assured. Most important, the adjustment of business investment could well be deeper and more extended than is currently assumed, while corporate restructuring could also lead to a more pronounced labor market shake-out, implying higher unemployment and lower consumption and residential investment. Another source of concern is the possibility of a "hard landing" in the United States, which would hurt Japan's external demand and underlying confidence.

\section{Difficulties associated with the "Y2K" problem could lead to temporarily} unsettled conditions around the end of 1999 and the start of 2000. Indications are that preparations in Japan, while initially slow, have accelerated substantially over the past year. ${ }^{11}$ Financial institutions were encouraged by regulatory agencies to be fully Y2K compliant by end-June 1999, while the BOJ announced its readiness to supply additional cash as needed toward the end of 1999. The preparedness of nonfinancial companies remains in more doubt, as in other countries, and uncertainties about the possible extent of $\mathrm{Y} 2 \mathrm{~K}$ disruptions are quite likely to lead to unusually high stockpiling in late 1999, effectively bringing forward demand from early 2000.

21. The difficulty in differentiating cyclical from structural factors makes the medium-term path of the economy hard to gauge. In the baseline forecast, the economy grows at an average rate of just over $2 \frac{1}{2}$ percent per annum from 2001 to 2005. In this scenario, the estimated output gap is closed, providing room to reduce the general government deficit excluding social security to close to 3 percent of GDP. However, activity has now been below estimated potential for most of the period since late 1992, which inevitably casts some doubt on the level and rate of growth of the potential output series (see Figure 1). ${ }^{12}$

22. The fiscal consequences of continued stagnation were analyzed in an alternative "low growth" scenario in which the growth in real activity after 2000 was limited to

\footnotetext{
${ }^{11}$ The Gartner Group recently upgraded its assessment of Japan's preparedness from the third tier to the second tier (out of four), along with France, Germany, and Italy, but behind the United States and United Kingdom.

${ }^{12} \mathrm{~A}$ paper by Bayoumi in the 1999 Selected Issues paper examines alternative approaches to calculating potential output in Japan. Based on this work, the staff's estimate of growth in potential output has been revised down, reflecting most importantly a cut in growth of trend total factor productivity.
} 
1 percent per annum (Table 3 ). With fiscal consolidation limited by the lack of a sustained recovery in output, the general government deficit (excluding social security) in FY2005 is assumed to remain close to its level in FY1999. In this scenario, general government net debt (excluding social security) rises to almost 140 percent of GDP, rather than stabilizing at 113 percent of GDP as in the baseline forecast (Figure 12).

\section{Assessment of the medium-term}

\section{external outlook also hinges on the}

expected growth trajectory. In the baseline scenario-which assumes a constant real exchange rate-the current account surplus is reduced over the next five years to around $2 \frac{1}{2}$ percent of GDP as Japan's economy grows more rapidly than trading partners, helping to reduce current account imbalances among the large industrial countries. Moreover, in this context, the yen would be likely to appreciate in real terms, contributing further to the adjustment of the current account towards an equilibrium saving-investment balance estimated at $13 / 4$ percent of GDP ${ }^{13}$ By contrast, in the "low growth' scenario, the current account surplus is projected to rise further to 4 percent of GDP, illustrating the sensitivity of the current account to domestic conditions.

\section{POLICY Discussions}

\section{Over the past year and a half, the Government has rightly focussed on measures} to stabilize the economy. The focus on short-term stabilization has, however, tended to weaken the incentives for the economic restructuring needed for a durable recovery. For example, since early 1998, stepped-up public investment has cushioned the over-sized construction sector. Moreover, the use of public money to guarantee bank loans and increase bank capital have raised concerns about moral hazard in the financial sector, and may have eased the pressure toward the necessary consolidation of the banking system.

\section{During the consultation discussions, the authorities clearly signaled their} intention to place increased emphasis on reforms to promote adjustment in the financial and corporate sectors, while maintaining the broad framework for macroeconomic support - an overall strategy that the staff fully supports. At this point, the scope for additional fiscal or monetary stimulus has been largely exhausted. With short-term prospects improved but still uncertain, the main task for macroeconomic policies is to ensure the steadfast implementation necessary to maximize the effectiveness of present plans. At the

\footnotetext{
${ }^{13}$ This figure is based on cross-country model estimated by the Research Department. See Isard and Faruqee (1998) for details on methodology.
} 
same time, there is a critical need to build the momentum of the reform process, with a view to ensuring a strong and profitable financial system, accelerating the pace and depth of corporate restructuring, creating new opportunities for profitable investment, and facilitating the reallocation of capital, labor and land. The adjustment process may well involve some painful transitions - including further land price declines and rising unemployment — which underlines the need for focussed efforts to strengthen social safety nets, ensure adequate financial regulation, and provide efficient mechanisms for corporate rehabilitation.

Nevertheless, in the absence of reform and associated supply-side improvements, any recovery in activity would be likely to be anemic and short-lived.

\section{A. Fiscal Policy: Stimulus vs. Consolidation}

26. Raising fiscal stimulus substantially beyond the level now planned would provide only a limited additional push to the economy even in the short term, while making more difficult the Ionger-term task of fiscal consolidation. While a large dose of fiscal stimulus has certainly contributed to stabilizing activity in recent months, officials pointed to the empirical evidence that fiscal multipliers are quite low to support their view that fiscal policy has generally been a less effective tool of demand management than anticipated. They also expressed concern that the growing market focus on fiscal sustainability observed since late 1998 had increased the sensitivity of long-term interest rates to news affecting the government's likely future borrowing requirements. The staff shares these concerns. On a variety of measures, Japan's government debt situation is already among the worst in the G-7 countries (Figure 13), and with the general government deficit excluding social security now approaching 10 percent of GDP, government debt ratios are on a steeply rising trajectory. This situation will only be redressed through a return to sustained growth and determined consolidation efforts over an extended period. ${ }^{14}$

\section{Notwithstanding the difficult long-term fiscal situation, the staff cautioned that} it would be premature to withdraw fiscal support before a recovery is well established. The staff's assessment is that further measures should be taken soon to avoid a drop-off in stimulus in the second half of the present year. As indicated above, staff estimates suggest that implementation of announced policies would raise the structural deficit of the general government by around 1 percent of GDP in FY1999. This figure is somewhat lower than initially estimated from the central government's budget documents since subsequent information on prefectural and municipal budgets suggest that local governments are

\footnotetext{
${ }^{14}$ The adjustment trajectory in the baseline forecast shown in Figure 2 is consistent with the objective of lowering the general government deficit excluding social security to 3 percent of GDP by FY2005, the fiscal target in the 1997 Structural Fiscal Reform Act (which was subsequently suspended as the recession deepened in 1998). However, such a trajectory would still leave government debt at a high level in the face of an aging population. Earlier staff analysis (see Okamura 1998) had suggested that the fiscal deficit would need to be brought below 1 percent of GDP to assure long-term fiscal viability.
} 
Figure 13. Japan: Comparative G-7 Fiscal Indicators, 1998

(In percent of GDP)
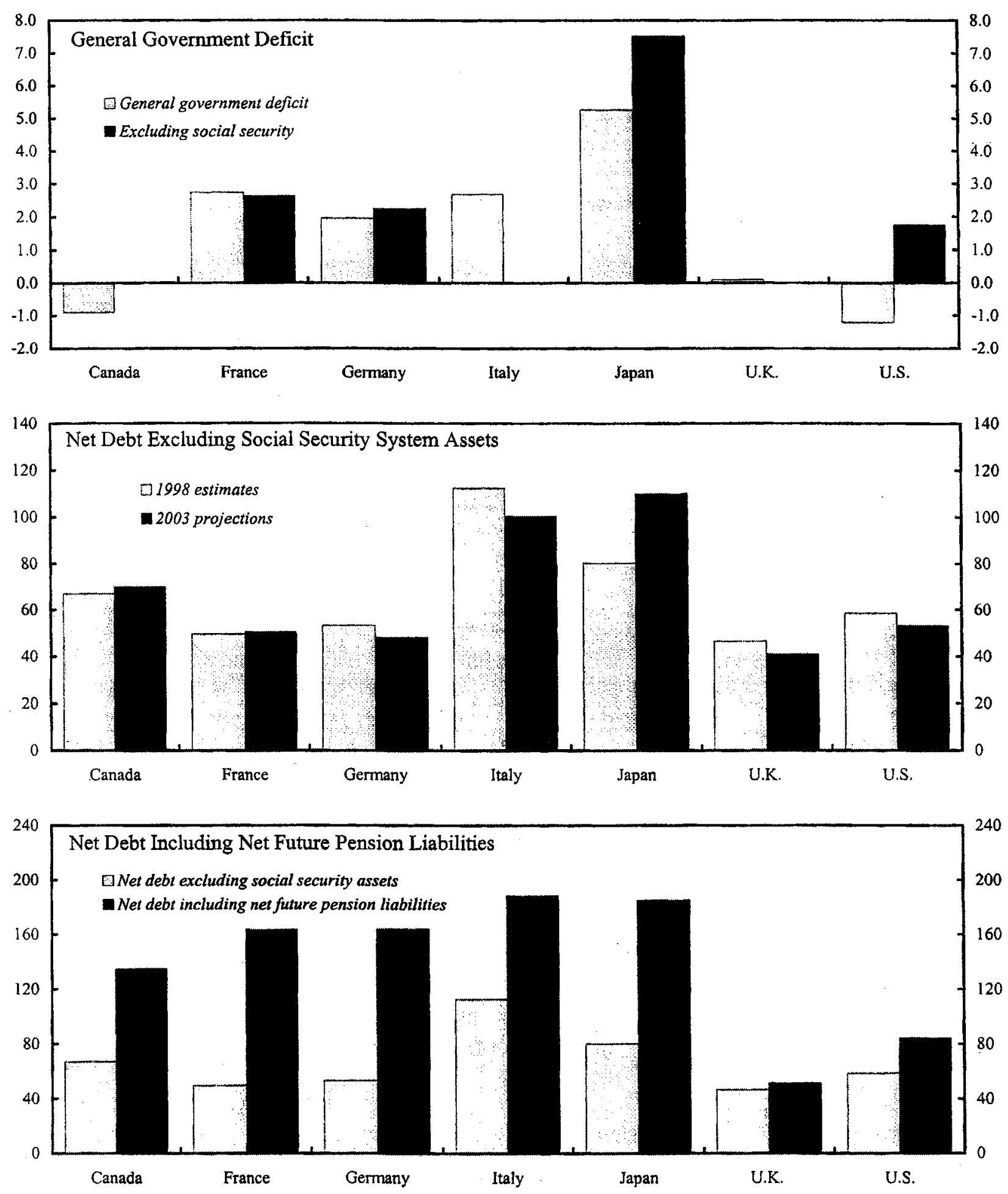

Sources: IMF, World Economic Outlook database; and Sheetal Chand and Albert Jaeger, Aging Populations and Public Pension Schemes, (1996). 
retrenching their investment spending, rather than putting in place the moderate increase implied by the indicative local government finance plan. ${ }^{15}$ Moreover, public works spending is likely to drop in the second half of FY1999 once the bulk of spending associated with the November 1998 stimulus package has fed through, unless additional measures are taken soon. Turning to FY 2000, staff recommended that policies be geared to maintaining the structural deficit close to its FY1999 level unless a sustained recovery was clearly underway, stressing that care should be taken to avoid a contractionary initial budget that would then need to be supplemented later in the year with additional measures.

\section{MOF officials responded that, depending on economic developments, the} Government would be prepared to take additional measures as needed to avoid a waning of stimulus. Officials commented that, in their view, the high level of central government investment spending in the FY1998 supplementary budgets and FY1999 budget would sustain public investment at very high levels throughout 1999, although some drop off could occur by early 2000 . A decision on the need for further measures would be taken around September, once release of the second quarter GDP outcome provided a better reading of the underlying strength of the economy and of the impact of fiscal measures already in place. For FY2000, it was still too early to reach a judgement on the appropriate stance, but officials agreed that significant fiscal consolidation would be neither possible nor desirable until a recovery was well entrenched.

\section{The need to ensure continued short-term fiscal support should not delay} progress with fiscal reforms aimed at laying the groundwork for eventual consolidation. Once it is clear that a recovery is under way, the structural deficit will need to be reduced gradually, as illustrated by the path shown in the baseline scenario. Learning from the bitter experience of 1997, however, the staff agreed with the authorities that in the present uncertain situation it would be premature to lay out a fixed schedule for fiscal consolidation.

Nevertheless, the staff stressed that early headway should be made with fiscal reforms that would help improve the efficiency and transparency of government operations, facilitate economic restructuring, and pave the way to an eventual consolidation plan once a recovery is solidly under way, thus helping to alleviate concern about fiscal sustainability.

- Public works. To achieve fiscal consolidation, the scale of public works spending will need to be curtailed drastically over the longer term. To set the stage, the staff suggested stepped up efforts to apply more effective cost-benefit analysis as the basic project selection tool across all types of project, to intensify measures aimed at

${ }^{15}$ Local government finances have been weakened in recent years by a combination of past stimulus measures and depressed tax revenues. In recent months, several prominent prefectures have announced spending cuts and other adjustment measures to avoid having their operations taken over by the central government. The central government is required to intervene in local government finances when the deficit exceeds 5 percent of budgetary expenditures. See Okue (1999). 
improving bidding and procurement procedures, and to accelerate plans to increase private sector involvement in infrastructure provision. The authorities responded that progress was being made-including in preparing a bill for a greater private sector role-but stressed the technical difficulties in comparing social rates of return on projects across different sectors.

- Social security. The staff emphasized the need for reforms that would reduce the build-up in pension outlays, and thus allow planned increases in the contribution rate to be delayed and moderated. Early adoption of such a plan would reduce overall uncertainty about the solvency of the system, which would tend to lower precautionary savings and therefore be positive from a short-term macroeconomic standpoint, although inevitably there would be distributional consequences. The authorities responded that alternative proposals to ensure the long-term viability of the pension system had been put forward, but a consensus had not yet been reached on whether to try to fix the current system (along lines proposed by the Ministry of Health and Welfare (MHW)) or to undertake more radical surgery involving privatization of the earnings-related segment of the system and full government financing of the basic pension component of the system (as suggested by the Economic Strategy Council). They noted that plans to reform the health care system were also being studied, with a view to controlling the build-up in costs, with special attention to the new program for nursing home care for the elderly. ${ }^{16}$

Tax reform. The staff suggested that recent reductions in personal and corporate income tax rates would eventually need to be followed by base-broadening measures, as well as an increase in the consumption tax, to ensure needed revenue growth as the proportion of retirees increases. ${ }^{17}$ Early introduction of tax-payer identification numbers (TINs) to allow more equitable treatment of different types of income and to bring more tax-payers into the base, reforms to encourage portable pensions and to facilitate labor mobility, and corporate tax reforms aimed at encouraging restructuring efforts should be the priorities. The authorities commented that such reforms were being actively considered by the Tax Reform Commission, but emphasized that major tax changes (such as the introduction of consolidated corporation tax) needed to be studied carefully to avoid undermining tax administration. They also noted the need to form a consensus in favor of politically difficult steps such as the introduction of TINs.

\footnotetext{
${ }^{16}$ This program - to be introduced in FY2000-is expected to have an initial cost of about 1 percent of GDP, of which 50 percent would be covered from insurance premiums, 25 percent from local governments, and the remainder from the central government. Some of the costs are expected to be recouped from lower hospital spending for elderly care.

${ }^{17}$ The maximum personal tax rate (combining central and local government taxes) was lowered from 65 percent to 50 percent in FY1999, while the corporate tax rate was lowered from 46 percent to 40 percent.
} 
- Transparency. The staff suggested that lack of transparency over fiscal operations makes it very difficult to assess the fiscal stance, and has probably been a factor limiting the macroeconomic impact of government stimulus packages; at a micro level, it also hindered scrutiny of government operations, raising uncertainty about the true financial positions of government enterprises. Box 3 provides an overall assessment of the strengths and weaknesses of the current system. The staff recommended that the government adopt a far-reaching plan to improve transparency, with the short-term goals of improving the timeliness of national income account information on recent fiscal operations, presenting budget proposals on a detailed consolidated basis for both central and general governments, and preparing fiscal projections for at least three years on a current policy basis. MOF officials recognized significant shortcomings in fiscal transparency, but were not hopeful that much could be done to improve the situation in the short term given the institutional constraints noted in Box 3.

\section{B. Monetary Policy in a Zero Interest Rate Environment}

30. The Bank of Japan (BOJ) has acted skillfully in unprecedented circumstances to continue to ease monetary conditions. The authorities explained that the recent decision by the BOJ to "maintain the current zero interest rate policy until deflationary concerns are dispelled"-characterized by some officials as being similar to adopting an inflation targeting approach - had been taken in response to market concerns that monetary policy might be tightened following the passing of liquidity pressures associated with the fiscal year end. Officials were encouraged that this announcement seemed to have helped convince markets of the BOJ's determination to avoid a deflationary spiral, as reflected in a further lowering of the yield curve through May.

31. While agreeing that the current policy stance was broadly appropriate, the staff discussed with the authorities whether further steps to increase transparency in the BOJ's policy framework could enhance the effectiveness of monetary policy in the present unusual circumstances. The initiation of regular publication of the minutes of the Monetary Policy meetings of the Policy Board over the past year has helped to raise the public's understanding of the BOJ's policy decisions. Acknowledging that the current conditions were largely uncharted territory, the staff suggested consideration of two further refinements to the present policy framework to allow even more explicit signaling of the BOJ's intentions:

- Clarification of the BOJ's ultimate price goal. The staff suggested that, given upward measurement bias, a CPI inflation target in the range $0-2$ percent could be justified as consistent with achieving price stability, which the BOJ is legally mandated to pursue. Officials responded that, in their view, market participants well understood the BOJ's overall commitment to price stability. Moreover, it was not necessarily desirable for the BOJ to focus on just one price index, since a range of indicators provided useful information. They also felt that announcing a specific target could 


\section{Box 3. Japan-Fiscal Transparency ${ }^{1}$}

\section{The fiscal system operates under well established procedures for legal and financial} accountability. Budget planning and execution are guided by constitutional and legal provisions that allocate clear responsibilities across government levels. The budget accounting system is comprehensive and accurate. Budget documents contain information on a number of contingent liabilities, including the amount of outstanding loan guarantees.

... but does not lend itself easily to macroeconomic analysis. Despite the accuracy of the Japanese fiscal accounts, it is extremely difficult for outside observers to monitor recent fiscal developments, to gauge the current stance of fiscal policy, and to assess the need for corrective measures. The main problems are:

- Lengthy data lags. The government publishes monthly information on its General Account and, on a more limited basis, on the 38 Special Accounts, but not in a form that readily allows for the construction of consolidated accounts for the central government. Consolidated accounts on general government operations are provided on an annual basis through the National Income Accounts, but these are published only with a lag of 12 months from the end of the fiscal year, owing to difficulties in combining the accounts of 3,200 local authorities.

- Limited information on the current fiscal stance. The budget documents provide only limited information on the consolidated fiscal position implied by the budget proposals. The frequent alternation of contractionary initial budgets and expansionary supplementary budgets further complicates the analysis, particularly since only limited information is provided on the timing of fiscal operations. As a result, cross-year comparisons can be highly misleading.

- Lack of detailed medium-term fiscal projections. With limited exceptions, mediumterm projections are constructed from mechanical extrapolation under different assumptions, rather than a detailed assessment of the future implication of existing commitments and policies.

- Extensive use of quasi-fiscal operations. The Fiscal Investment and Loan Program (FLP) continues to be used to advance fiscal objectives that elsewhere would be carried out on the central government budget. For example, the FILP was used to provide funding needed to temporarily absorb losses associated with the privatization of the Japan National Railways. Moreover, agencies funded through the FILP are shielded from capital market scrutiny. While the default rate for current FILP agencies has been low, future contingent liabilities from such operations are difficult to assess.

Scope for improvement. Government officials are well aware of the problems relating to the lack of macroeconomically relevant information, and have made efforts to provide more information on a consolidated basis in recent budget documents. While there should be further scope to enhance data provision, in the end achieving best practices in fiscal transparency would require fundamental reforms to the legal and institutional fiscal framework. Some of the largest obstacles include (i) the use of Special Accounts under the control of individual ministries; (ii) the reliance on stimulus packages implemented through large supplementary budgets that diminish the importance of initial budgets; and (iii) the reliance of most FIL agencies on direct financing or explicit government guarantees (which appears likely to continue even after planned FILP reforms in 2001).

${ }^{1}$ This box draws on the paper by Mühleisen in the 1999 Economics and Policy Developments paper. See also Bayoumi (1998) for details on institutional arrangements. 
constrain their flexibility in responding to developments, pointing to the period in the late 1980 s when continued subdued prices had not signaled a need to tighten monetary conditions in the build-up to the asset price bubble.

Adoption of a supplementary operating target to signal intended changes in the monetary policy stance, now that the overnight rate has fallen to its effective floor. The staff suggested use of a quantitative indicator such as base money or a term interest rate further out the yield curve. Officials responded that the monetary base would not make a satisfactory target because it was highly volatile and not a good indicator of monetary conditions (Figure 14). Moreover, the base was increasingly difficult to control since most banks' demand for excess reserves was now saturated. ${ }^{18}$ Some officials acknowledged that using term interest rates as a supplementary indicator would be easier to integrate with the primary objective of keeping short-term rates at zero, but they pointed to the difficulties in controlling interest rates of term instruments and noted that interest rates out to one year were already below 10 basis points.

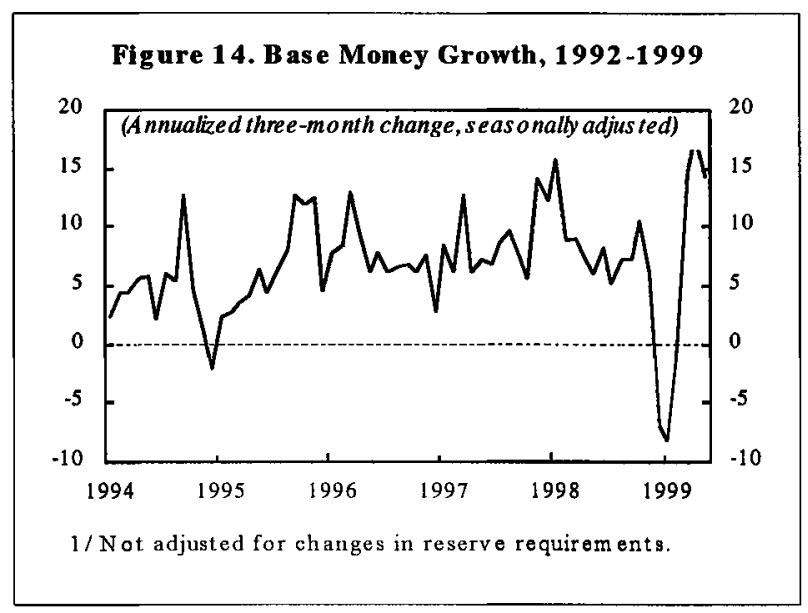

32. If deflationary pressures threatened to intensify, there remains some scope to increase monetary stimulus. While the deflation risk seems to have been alleviated for now, in the event of renewed downward price pressures there could be a need for further steps to ease the monetary stance. In discussing this issue, some officials felt that the impact of further conventional liquidity injections would be limited, because financial institutions would simply redeposit much of the excess liquidity at the BOJ. However, they acknowledged that there remained room to extend monetary operations out the yield curve, although they would need to be careful to continue to ensure the high quality of the BOJ's asset base.

33. Exchange rate management has to balance concerns for the economy's cyclical position with the need to ensure stable market conditions. The staff expressed concern

\footnotetext{
${ }^{18}$ Officials pointed out that the BOJ's commitment to a zero rate policy had actually reduced bank demand for liquidity as they could rely on short-term funding from the BOJ without cost, which explained the decline in the monetary base in recent weeks.
} 
that the yen had been allowed to rise so strongly in the second half of 1998, which implied a considerable tightening in monetary conditions despite the weak economy, but welcomed the apparent shift in the authorities' attitude since early 1999. MOF officials said that in their view movements in the exchange rate to extreme levels in either direction would be undesirable. They emphasized that they would be concerned about a premature and rapid strengthening of the yen as long as the economy remained weak. The authorities agreed with the mission that some further moderate weakening of the yen could be helpful from a cyclical perspective, but would want to avoid a rapid depreciation that could disrupt market conditions and undermine sentiment in domestic and international markets. More generally, however, they noted that there were limits on how far it was possible to influence market developments through intervention.

\section{Dealing with Banking Problems}

\section{While most of the basic tools are now in place, vigorous implementation is still} needed to fully resolve banking problems before the scheduled reintroduction of limited deposit insurance cover in April 2001. The authorities emphasized that the framework for resolving banking strains is now largely in position, and that a solid start has been made in applying the new instruments, helping to strengthen the balance sheets of most of the major banks and allaying concerns about financial turbulence. Nonetheless, senior officials agreed with the staff that much remained to be accomplished before removing full deposit insurance coverage. Key tasks include maintaining supervisory pressure to ensure adequate levels of provisioning; returning banks falling under public control to the private sector; improving mechanisms for disposing of bad loans; and encouraging the trend towards consolidation as a means to boost bank profitability towards international levels.

\section{The discussions focussed on the need for an aggressive and comprehensive} strategy to deal with these issues. The staff suggested that the approach should be centered on further efforts to tighten regulatory standards, particularly with regard to bad loan recognition and capital adequacy; ensuring that additional public funds are provided only under appropriately tough conditions aimed at ensuring the exit of surplus capacity and mitigating moral hazard concerns; and steps to expedite the timely resolution of bad debts held by public agencies:

- Bad loan recognition. Notwithstanding further heavy loan loss charges incurred by major banks in FY1998, the staff expressed concern that provisioning against existing bad loans remains inadequate - particularly "special mention" loans (Category II) and that the continued weakness of the economy was generating new bad loans that had yet to be recognized. Regulatory officials responded that standards were now more rigorously and more uniformly applied than in the past. Nevertheless, they accepted that new bad loans from the current downturn may not yet have been 
adequately provisioned against, and that it would be important to maintain supervisory pressure in this area.

- $\quad$ Recapitalization with public funds. The staff suggested that the leverage implied by government holdings of preferred shares from public capital injections should be used to ensure that receiving banks achieved performance goals and to encourage needed consolidation of the banking system. Moreover, across-the-board injection of capital into the small regional banks should be avoided, since this would prolong the life of unprofitable entities and raise moral hazard concerns. Officials responded that the implementation of major banks' restructuring plans would be monitored closely, and that the FRC would be ready to issue improvement orders and convert preferred shares into ordinary shares - powers not available earlier-if a bank's capital adequacy ratio deteriorated sharply. On capital injections into regional banks, officials indicated that, in principle, public funds would be concentrated on "indispensable" regional banks. Subsequent to the discussions, guidelines were announced for such capital injections, giving priority to banks involved in active restructuring through alliances or mergers, and also requiring banks receiving funds to achieve sufficient capital adequacy after the capital injection, with 8 percent as a desirable target.

Nationalization and "bridge bank" operations. The new framework for intervening in failed banks is working much more smoothly and flexibly than in the past, but an effective means to transfer operations back to the private sector has yet to be demonstrated. The staff stressed that if buyers could not be quickly found for a nationalized bank as a going concern, then the marketable assets of the bank should be sold separately to investors and other assets transferred to the RCC. Officials agreed that every effort would be needed to ensure rapid resolution of nationalized or bridge banks, and said that they were hopeful that a buyer could soon be found for the LongTerm Credit Bank.

- Capital adequacy. The staff commented that recent bank failures had demonstrated that measured capital adequacy may provide little indication of a bank's true financial position, and encouraged the authorities to tighten standards by April 2001. Beyond the underestimation of provisioning against bad loans, weaknesses of the current methodology include use of book rather than market value for valuing securities by virtually all major banks and the inclusion of excessive deferred tax assets within tier-1 capital. ${ }^{19}$ Moreover, banks with only domestic operations are only required to hold 4 percent capital (2 percent Tier-1), well below international standards. Officials

\footnotetext{
${ }^{19}$ Deferred tax assets relate to anticipated future tax deductions for loan losses against loans that have already been provisioned against, although the value of such an asset depends on the bank earning future taxable profits. For major banks in Japan, such assets amount to around $¥ 7$ trillion, or one third of tier-1 capital. In the United States, such assets may not constitute more than 10 percent of tier-1 capital for an individual bank.
} 
responded that, in their view, the methodology for calculating bank capital was adequate, noting that mark-to-market accounting was to be required for all banks by 2001 and that regulators had flexibility to limit use of tax-deferred assets when appropriate. They recognized that it would be desirable in principle to raise capital adequacy for domestic banks but emphasized the difficulty of raising the standard for domestic banks while the economy remained weak.

Loan disposal. While adequate provisioning is a key first step, reallocation of the resources tied up in over-indebted enterprises requires active resolution of bad loans. Some progress is now being made, following more generous tax treatment of debt forgiveness in out-of-court settlements and legislation to facilitate securitization. The staff suggested that the newly formed RCC should play a leading role in this effort by acting aggressively to recover value from nonperforming assets obtained from failed or nationalized institutions, including through foreclosure and asset sales. Officials responded that the loan disposal process was now gathering momentum as the RCC learned from past experience of loan collection. The RCC was still assessing how best to use its new authorities to purchase bad loans from viable institutions.

- Deposit insurance system. Officials shared the staff's concern that the premature replacement of the present blanket coverage with limited coverage while the banking system remained weak could precipitate destabilizing deposit withdrawals at banks that were perceived to be under-capitalized. However, they emphasized that the continued existence of blanket deposit insurance raised moral hazard concerns, and that its expected removal was important to maintain pressure on banks to restructure. Possible reforms to the deposit insurance system - including questions of coverage and pricing - and the need to maintain an adequate framework for resolving failed banks, which is also set to expire at end-March 2001 — were now being studied, with a view to bringing legislative proposals to the Diet by early 2000 .

\section{Financial Reforms and Corporate Restructuring}

\section{The staff shares the view held by many observers in both the government and} the private sector that a sustained improvement in economic performance will depend on dealing with a series of weaknesses that have emerged in the financial system and corporate structure. In recent years, it has become increasingly apparent that Japan's markets and institutions have adjusted too slowly, and that an economic structure that in the past had delivered strong growth is no longer as well suited to meeting challenges posed by an increasingly global environment and an aging population (Box 4). The Government has taken a number of important steps towards addressing key weaknesses, including putting in place a framework to deal with banking problems, pushing through sweeping "Big Bang" financial reforms, and a number of deregulation initiatives. However, while these steps have prompted a gathering response from the private sector, the process is far from complete. The challenge 


\section{Box 4. Corporate Weakness and the Emerging Response ${ }^{1}$}

The position of the Japanese corporate sector has changed dramatically over the past ten years. At the end of the 1980s, Japanese businesses and financial institutions were among the largest and most rapidly growing in the world. Now, while some firms still retain their global leadership, much of corporate Japan suffers from weak balance sheets, excess costs, and low profitability. Returns on assets have fallen to only 2 percent, half their historic average and far below U.S. levels.

Attributes that were once seen as strengths of the Japanese system have now emerged as weaknesses. In part, the erosion of corporate profitability is related to over-investment and excessive build-up of indebtedness in the bubble period, the adjustment to which has both contributed to and been complicated by the growth slowdown of the 1990s (see Box 1). More fundamentally, Japanese businesses and markets have not yet made the necessary transition from a structure relying on heavy capital accumulation and rapid export growth to one placing greater emphasis on innovation, productivity growth, and efficient use of resources.

- Despite deregulation initiatives and tariff cuts, competition is still weak in domestic markets, in large part because of remaining barriers to entry and extensive administrative controls. As a result, input costs are high and start-ups are discouraged.

- Reliance on the "lifetime employment system", seniority-based pay structures, and defined benefit pension schemes have implied rising employment costs and limited labor mobility as the workforce has matured.

- The "main bank" system of corporate governance has lost effectiveness because banks no longer have the financial strength to act pre-emptively to deal with emergency problems, while large firms raise funds more directly from capital markets. However, "Anglo-Saxon style" capital market discipline is not yet in place, hampered by still extensive cross shareholdings and by lax accounting standards. In practice, losses have often been obscured by shifting them to partly owned subsidiaries.

- Corporate rehabilitation is complicated by the complexity and cost of bankruptcy procedures, especially the lack of a well functioning "Chapter II" restructuring code.

Corporate restructuring has accelerated over the past year. Change has been most apparent in the financial services sector, in response to new opportunities and heightened competition created by "Big Bang" reforms. Steps toward consolidated accounting and increased supervisory pressure on banks to recognize problem loans have also encouraged adjustment in other sectors too. Restructuring programs have included reductions in employment through hiring freezes and early retirement schemes; a shift toward merit-based salary structures; consolidation of production facilities; sales of loss making subsidiaries; partnerships with foreign investors; and out-of-court debt workouts for some overindebted trading and construction companies.

While these plans make headlines, to date their scale remains limited and implementation is still at an early stage. For example, employment reduction targets are typically of the order of 10 percent over 3-5 years, and considerably less ambitious than typically achieved in U.S. firms that have undergone restructuring. Many market analysts suggest that in the end the scale of change will need to be much deeper to restore adequate rates of return on assets.

${ }^{1}$ This box is based on material in Levy in the 1999 Selected Issues paper, Morgan Stanley (1999), and Oishi and Towe (1998). 
will be to foster an environment conducive to vigorous and effective restructuring, while limiting the transitional strains. Beyond the banking system issues discussed above, key elements of such a strategy would include: continued financial reforms to reduce the role of public institutions in financial intermediation and ensure strong financial regulation and supervision; tax and legal reforms to enhance the tools for corporate restructuring; measures to improve labor mobility and strengthen the social safety net; and adoption of a more comprehensive approach towards deregulation.

\section{The "Big Bang" reforms need to be complemented with steps to scale back the} public sector's role in financial intermediation. The legislative framework for the "Big Bang" is now virtually in place, and most items will have been implemented by October 1999. More competitive and transparent capital markets together with the phased introduction of tighter accounting standards are already increasing pressure on Japanese businesses to raise returns on capital. Building on this progress, the mission stressed that the government should press ahead with a broader set of measures focussing on steps to curtail the continuing role of the public sector in financial intermediation. While planned reforms in this area move in the right direction, they do not go far enough to curb the privileged position of the post office system or to reduce the role of the GFIs. ${ }^{20}$ Officials responded that in their view the reforms now being prepared would go a substantial way to improving transparency and financial responsibility of public financial institutions, while emphasizing that such institutions continued to play an important role in the Japanese financial system.

\section{Continued efforts will also be required to strengthen the new financial} supervisory structure, and in particular to deal with weakness in the life insurance industry. Shortly after the mission, a mid-sized life insurer was ordered to suspend operations, the second such failure in two years and the first since the introduction of new prompt corrective action procedures. During the discussions, FSA officials observed that other life insurance companies were in better financial condition; the remaining 15 large and mid-sized life insurers all satisfied the solvency margin requirements at end-March 1999. Nevertheless, the FSA is only now embarking on detailed inspections of asset quality and, as occurred with banks, would be applying pressure to improve standards. Private analysts expressed concern about deteriorating asset quality and negative spreads between investment returns and yields promised to policyholders. New life insurance policies are already declining

\footnotetext{
${ }^{20}$ At present, around one third of private saving is channeled by the post office savings system through the FILP to fund government lending institutions, a system that lacks transparency, is likely to misallocate resources, and undermines profitability of private sector financial intermediation. The government has developed a blueprint for reforms which would end the automatic deposit of post office savings and pension contributions with the Trust Fund Bureau for investment through the FILP, allowing independent investment decisions by a corporatized post office savings system and requiring some FILP agencies to raise funds directly on the market.
} 
quite sharply, and, as with banks, strains could mount in the run-up to the removal of the extensive government guarantee to the policyholder insurance scheme in April 2001.

\section{A range of further tax, legal, and accounting reforms are needed to facilitate corporate restructuring and to cushion the transitional costs, particularly on employees. Following recommendations by the Economic Strategy Council (ESC) for sweeping changes in this area (ESC 1999), the Government has set up an Industrial Competitiveness Panel to make specific recommendations on needed reforms. These proposals were being actively considered during the Article IV mission, and some elements were included in the June 1999 jobs package and in recent tax proposals to support restructuring.}

- Tax and legal framework for corporate restructuring. The staff broadly supported the ESC's proposals-including extended loss carry-over periods to encourage scrapping of excess capital equipment, capital gains exemptions on transferring land and equities into new companies, and a commitment to introducing consolidated taxation. However, the staff also warned against steps that could allow excessive concentration of ownership or further entrench cross-share holdings (including, for example, a proposal to allow companies to transfer shareholdings to pension schemes while retaining voting control). Officials responded that the various reform proposals from the ESC and also the employers' organization (the Keidanren) were being actively discussed, although care would be needed to ensure that the long-term goals of the tax and legal systems were not undermined for short-term objectives. In the end, the tax and regulatory measures announced in June after the mission left (see paragraph 16, bullet 4) were somewhat narrower in scope than the range of measures under discussion.

- $\quad$ Measures to support labor mobility and strengthen the social safety net. Impediments to labor mobility in Japan include inefficient job search and a pension system that penalizes changing positions. The staff emphasized the need for taking a market oriented approach, including a further liberalization of restrictions on temporary employment and tax changes that would improve the portability of pension plans (including introduction of defined contributions schemes). At the same time, short-term transitional costs could be reduced by strengthening coverage of the unemployment insurance system (including extending the short duration of unemployment benefits). Officials responded that such steps were being studied, but expressed concern that care would be needed to avoid shifting too far towards a European-style system that could lead to a rise in long-term unemployment. In the event, the June package focussed mainly on steps to extend eligibility for government retraining programs as well as additional funds to support creation of additional jobs in the public sector and to subsidize new jobs in the private sector.

- Bankruptcy reform. Japan's present bankruptcy law is cumbersome and emphasizes protection of creditor rights through liquidation. While a variety of mechanisms exist 
for court-supervised reorganization, these have not proved effective tools for corporate rehabilitation, which may have contributed to unnecessary liquidations in the face of corporate insolvency. Officials explained that reforms now being prepared would create a structure more similar to "Chapter 11" in the United States, allowing management to stay in place after filing for bankruptcy protection, allowing courts to impose temporary stays on secured creditors, and requiring majority rather than unanimous creditor approval of restructuring plans. While welcoming the broad thrust of these plans as a potentially important step to ease transitional costs related to insolvency, the staff expressed concern that the legal system's capacity to handle a sharp increase in the number of bankruptcy cases would be limited, and suggested that steps could also be taken to set up an out-of-court mediation process, as for example has been done effectively in the United Kingdom. Officials responded that while this proposal had been considered, in the Japanese context there were advantages in relying on legal processes to allocate losses fairly between debtors and creditors.

40. Regulatory reform needs to be rooted in comprehensive sectoral reform plans. A recent OECD study of regulatory reforms in Japan (OECD 1999) concluded that, notwithstanding some successes, the deregulation process has been largely ineffective, as markets remain distorted and uncompetitive and foreign participation continues to be discouraged. The WTO secretariat has highlighted the continuing inefficiencies arising from lack of transparency and non-tariff barriers to trade, particularly those protecting the agricultural sector (WTO 1998). What is needed is to replace the past incremental approach to deregulation and trade reform that has been too easily subverted by entrenched bureaucratic and sectional interests with comprehensive and convincing reform strategies in key areas. Priorities include elimination of demand-supply balancing requirements in the transportation sector, facilitating competition in the telecommunications sector through transparent and low cost connection fees, completion of liberalization in the petroleum, power and retail sectors, and reduction of remaining non-tariff barriers to trade in agricultural products.

\section{E. Other Issues}

41. Japan is the largest provider of ODA. In 1999 ODA rose to 0.3 percent of GDP, returning to its 1992 ratio, reflecting the substantial Japanese efforts to provide financing for countries affected by the Asia crisis. The mission encouraged the increased efforts to augment resources for the least developed countries and for social objectives.

\section{Continuing weaknesses in the economic data complicate the monitoring of} developments and the formulation of macroeconomic policies (Annex II). The mission stressed the need to take steps to address long-standing problems related to the shortage of consolidated information on fiscal accounts and the timeliness and coverage of the national income accounts, issues which were particularly problematic in present circumstances in which fiscal policy was being actively used as a stabilization tool and the underlying strength of the economy was particularly hard to read. Officials in the Economic Planning Agency indicated 
that improvements in timeliness of the national accounts data were now being studied, but expressed concern that early release of "flash" estimates would imply less reliable numbers. Subsequently, it was decided that flash estimates would be published, but for a trial period publication would still be simultaneous with the release of the full quarterly estimates around ten weeks after the end of the quarter (a longer lag than for most other major industrial countries) (EPA 1999).

\section{STAFF APPRAisal}

43. Faced with an unprecedentedly intense down-turn in activity and a turbulent external environment, the authorities have implemented over the past year and a half a wide-ranging series of fiscal, monetary and banking initiatives to support the economy and relieve financial strains. These policies have contributed importantly to the growing signs of a bottoming out of activity, to a turnaround in business confidence and market sentiment, and to averting the immediate threat of a deflationary spiral or financial collapse.

44. Despite these gains, a sustained recovery is still by no means assured. The corporate restructuring that is now in progress is necessary to finally resolve the excesses of the bubble period and to restore the vigor and profitability of Japanese business. However, in the short term, restructuring will continue to weigh on both nonresidential investment and household spending. The staff forecasts a return to modest growth in 1999 and 2000 , but the downside risks remain significant.

\section{In the staff's view, the government's evolving strategy_giving increased} emphasis to structural reforms while maintaining macroeconomic support-is the correct one. While the scope for additional fiscal or monetary stimulus is now limited, it is still too early to start unwinding the support for aggregate demand from macroeconomic policies. At the same time, recent signs of short-term improvement in activity should not be allowed to detract from efforts to foster the adjustment to underlying structural problems in the banking and corporate sectors without which an enduring recovery will not be possible. Although the private sector bears the main responsibility for restoring Japan's economic dynamism, the government must ensure that the policy environment is conducive to restructuring. Moreover, because the adjustment process brings it own risks-including increasing unemployment and risks of financial failure-attention must also be paid to strengthening social safety nets and to ensuring strong financial regulation.

\section{Notwithstanding the longer-term need for fiscal consolidation, the present} supportive fiscal stance should be sustained until a recovery of private demand takes hold. The priority should be to ensure that the fiscal stimulus intended for FY1999 is delivered in full, despite lower than anticipated spending by financially constrained local governments, and then sustained through FY2000: 
- Public investment. Following a rapid build-up in early in 1999, public works spending is likely to decline significantly during the second half of the year (on a seasonally adjusted basis) unless additional measures are taken soon. Given the uncertain outlook for private demand, planning for a further round of public works spending should not be delayed.

- $\quad$ FY2000 budget. It will be important to signal at an early stage that fiscal stimulus will not be withdrawn in FY2000 before a sustained recovery is well established.

47. Besides maintaining fiscal stimulus, it will be important to push ahead with fiscal reforms to lay the groundwork for eventual consolidation. While it is still too early to lay out a detailed schedule for needed long-term fiscal consolidation, there is scope to take action to improve the efficiency and transparency of government operations and lay the ground-work for consolidation once a self-sustaining recovery is achieved:

- Social security. Comprehensive reforms are needed to ensure the long-term viability of the public pension system. Recent proposals to control costs in order to limit future rises in contribution rates would provide a significant step forward. However, care is needed to avoid placing an extra burden on the government's budget.

- Public works. To enhance the efficiency of spending, it will be useful to extend recent initiatives to apply cost-benefit analysis, to improve bidding and procurement procedures, and to accelerate plans to increase private sector involvement.

- Tax reform. Welcome recent cuts in personal and corporate income tax rates need to be followed by reforms to broaden the tax base, to increase the portability of pensions, and support corporate restructuring plans.

- Transparency. Short-term goals could include the timely release of detailed consolidated data on past operations, as well as budgetary projections for central and general governments on a current services basis.

48. The staff supports the BOJ's commitment to maintaining a zero interest rate policy until deflationary concerns are dispelled. The recent easing of monetary policy by the Bank of Japan (BOJ) is providing critical support for the economy, and thus helping to alleviate immediate deflationary anxieties. Nevertheless, should price declines intensify significantly - a development that now seems less likely but cannot be ruled out-the BOJ will need to find means to apply additional monetary stimulus, for example, by extending monetary operations up the yield curve and broadening the range of assets involved in such operations. In such a difficult situation, the staff would also suggest further steps to increase transparency in the BOJ's policy framework-such as making the BOJ's long-term price goal more explicit and adopting a supplementary operating target to signal intended changes in the monetary policy stance. While recognizing the BOJ's concerns in this area, the staff feels that in such 
difficult circumstances, priority would need to be given to demonstrating the BOJ's determination to fight deflationary dangers.

49. Given the uncertain state of the economy, the authorities have acted prudently in recent weeks to resist a substantial strengthening of the yen. At the same time, consistent with maintaining an easy monetary stance, the authorities should be ready to tolerate further moderate yen depreciation while taking care to avoid unstable market conditions. At this point last year, the staff's exchange rate advice was more circumspect in view of concerns that yen weakening could destabilize conditions more broadly in East Asia. However, such concerns now appear less pressing as the yen is now considerably more appreciated and regional exchange rates seem to have become less sensitive to yen movements.

50. The effective framework for resolving banking strains that has now been put in place has reduced the immediate risk of financial turbulence. However, further initiatives are still needed to ensure that the sector is restored to full health and to encourage the consolidation within the sector needed to raise profitability towards international levels. Such actions are particularly important given the planned reintroduction of limited deposit insurance coverage after March 2001:

- $\quad$ Supervision. Continued pressure is needed on banks to classify loans appropriately and to raise provisioning against bad loans, particularly since persistent weakness in activity would contribute to the further deterioration of loan portfolios. Supervisory resources must continue to be increased rapidly.

- $\quad$ Recapitalization with public funds. Pressure must be maintained on receiving banks to achieve their performance goals. Future capital injections should be targeted at encouraging bank consolidation.

- Nationalization. Every effort is needed to ensure that nationalized banks are quickly returned to the private sector, including by selling marketable assets of the bank separately to investors if buyers cannot be quickly found for such banks as going concerns.

- Capital adequacy standards. Most important, the minimum capital standard should be raised progressively to 8 percent for all banks by March 2001, although this would need to be done in stages to moderate any initial negative impact on bank lending. $\mathrm{A}$ limit on the inclusion of excessive deferred tax assets within tier-1 capital would also help to reinforce capital standards.

- Loan disposal. The newly formed RCC should act aggressively to dispose of nonperforming assets before their value erodes. The acquisition of bad loans from 
viable institutions should be approached cautiously, since the RCC could come under pressure to acquire loans at an excessive price.

- Deposit insurance. The planned reintroduction of partial deposit insurance in April 2001 has provided an important spur to bank efforts to strengthen their financial positions quickly. The authorities need to be careful to design a robust structure for the new system-including a well-financed deposit insurance fund and efficient mechanisms to deal with failed institutions.

\section{More broadly on the reform front, priority should be given to pushing through} initiatives to strengthen the financial structure, enhance the environment for corporate restructuring, and foster greater labor mobility and accelerate deregulation. Key ingredients include:

- Reduction of the public sector's role in financial intermediation. The successful implementation of the "Big Bang" program should be complemented by further steps to reduce the role of the public sector in financial intermediation. While planned reforms move in the right direction, FILP agencies should be funded as far as possible through the market. Moreover, planned reforms to the postal saving system should go further toward curbing its privileged position, paving the way for eventual privatization.

- Strengthening of regulatory oversight of the broader financial system. The FSA's recent efforts to tighten supervision of the life insurance sectors are welcome, and will need to be followed through forcefully.

- Reform of the bankruptcy code. The acceleration of plans to provide a more flexible approach to corporate rehabilitation under "Chapter 11" type protection provides an important step toward dealing more rapidly with severe corporate stress, and thus easing transitional pains related to insolvency.

- Reforms to encourage greater labor mobility and strengthen the social safety net Accelerated corporate restructuring will inevitably create strains in labor markets. In responding to such strains, the emphasis should be on steps to enhance market functioning and relieve social costs-for example, further liberalization of restrictions on temporary and over-time work and extension of the period of eligible benefits for unemployed persons-rather than direct government involvement.

- Deregulation and trade. The staff supports the OECD secretariat's call for renewed impetus to deregulation through comprehensive sectoral programs, and the WTO secretariat's emphasis on steps to reduce non-tariff barriers to trade. Such actions could help generate increased competition, improved productivity, and new investment, thus boosting prospects for a sustained recovery. 
52. Continuing weaknesses in the economic statistics complicate the monitoring of developments, and the formulation of macroeconomic policies. This is a serious concern, particularly with regard to the fiscal and national accounts data, and a high priority should be placed on improving the timeliness and coverage of these statistics, even at the expense of some temporary loss in reliability until new data collection methods can be installed.

53. Japan remains the world's largest provider of ODA. The initiatives taken over the past year to provide increased financial support to East Asia crisis countries, notwithstanding Japan's own internal difficulties, have played an important part in fostering a strong regional recovery.

54. The next Article IV mission is proposed to take place on the standard 12-month cycle. 


\section{References}

Atkinson, D., "Bank March 2003 Profit Forecasts: Spectacular Lack of Any Real Change", Goldman Sachs Japan, March 24, 1999.

Bayoumi, T., "The Japanese Fiscal System and Fiscal Transparency", in Structural Change in Japan: Macroeconomic Impact and Policy Challenges, edited by B. Aghevli, T. Bayoumi and G. Meredith (Washington: International Monetary Fund, 1998).

Bayoumi, T., C. Towe and I. Oishi, "Fiscal Policy Issues", in Japan-Selected Issues (Washington: International Monetary Fund, October 1998).

Bayoumi, T., "Monetary Policy Issues", in Japan - Selected Issues (Washington: International Monetary Fund, October 1998).

Bayoumi, T., "The Morning After: Explaining the Slowdown in Japanese Growth in the 1990s", IMF Working Paper WP/99/13 (Washington: International Monetary Fund, January 1999).

Economic Planning Agency, "Handling of Flash Estimates of Quarterly GDP”, May 24, 1999.

Economic Strategy Council, Strategies for Reviving the Japanese Economy, February 1999.

Isard, P. and Hamid Faruqee, "Exchange Rate Assessment" in Extensions of the Macroeconomic Balance Approach, IMF Occasional Paper No. 167 (Washington: International Monetary Fund, 1998).

Morgan Stanley Dean Witter, Japan Restructuring, May 1999.

Morsink, J., "Financial Sector Reforms: Opportunities and Challenges", in Japan-Selected Issues (Washington: International Monetary Fund, October 1998).

Organization for Economic Co-Operation and Development (OECD), The OECD Review of Regulatory Reform in Japan, February 1999.

Okamura, K., Japan's Medium- and Long-Term Fiscal Challenges", in Structural Change in Japan: Macroeconomic Impact and Policy Challenges, edited by B. Aghevli, T. Bayoumi and G. Meredith (Washington: International Monetary Fund, 1998).

Okue, K., Filling the Vacuum: Japan Policy Monitor, Dresdner Kleinwort Benson Research Paper (April 16, 1999), Tokyo. 
Shiratsuka, Shigenori, "Measurement and Errors and the Quality Adjustment Methodology: Lessons from the Japanese CPI," Economic Perspectives, Federal Reserve Bank of Chicago, Second Quarter, 1999.

Oishi, I., and C. Towe, "Governance, Deregulation, and Economic Performance", in Japan—Selected Issues (Washington: International Monetary Fund, October 1998).

Posen, A., Restoring Japan's Economic Growth, Washington: Institute for International Economics, 1998.

Ramaswamy, R., and Christel Rendu, “Japan's Stagnant Nineties: A Vector Autoregression Retrospective", IMF Working Paper WP/99/45 (Washington: International Monetary Fund, April 1999).

Woo, D., "In Search of "Capital Crunch": Supply Factors Behind the Credit Slowdown in Japan”, IMF Working Paper WP/99/3 (Washington: International Monetary Fund, January 1999).

World Trade Organization, Japan-Trade Policy Review, Report by the Secretariat, January, 1998. 
Table 1. Japan: Selected Economic Indicators, 1992-2000

Nominal GDP: US\$3,783 billion (1998)

Population: 126.3 million (1998)

GDP per capita: US\$29,937 (1998)

Quota: SDR 8,241.5 million

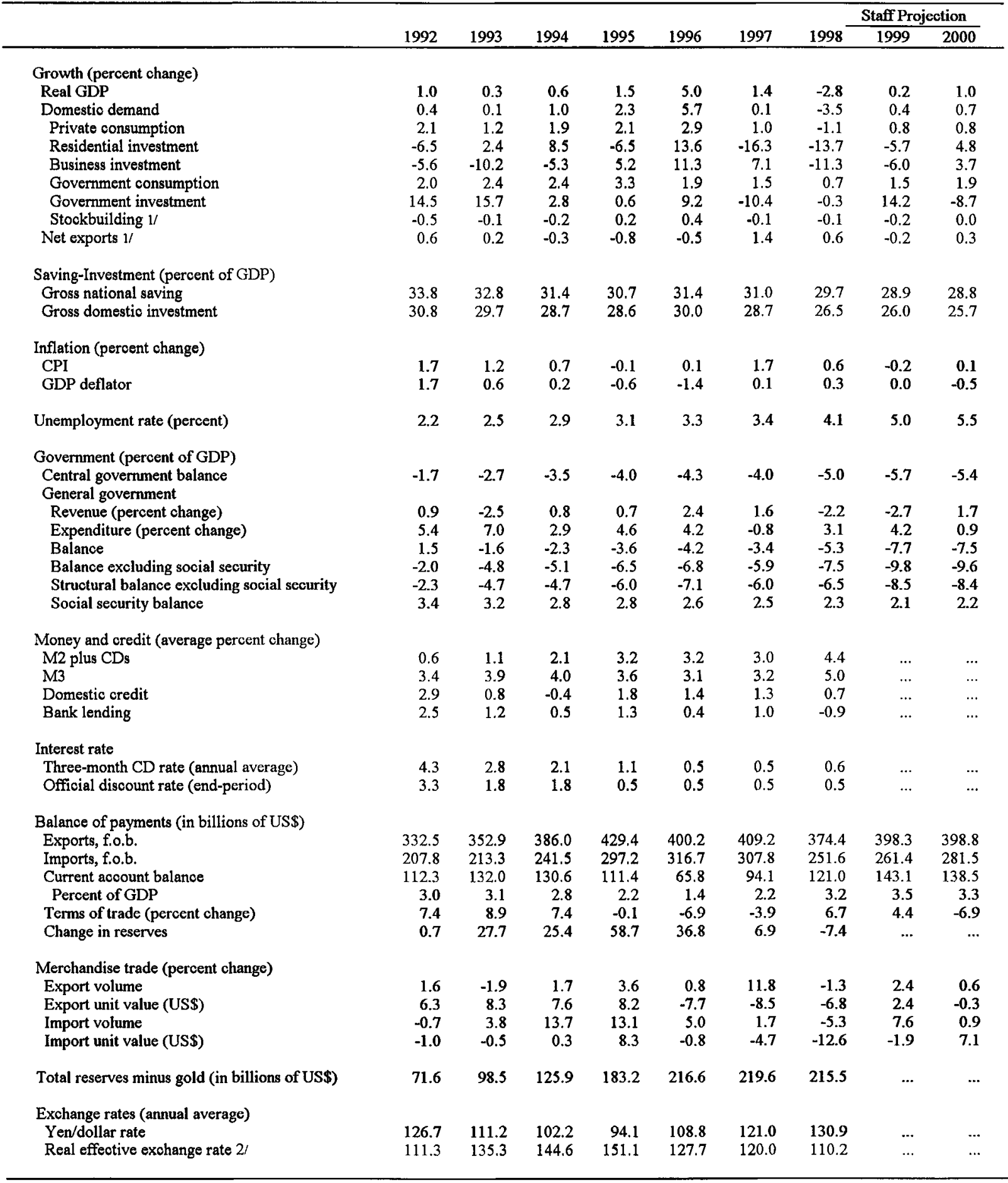

Sources: Nikkei Telecom; and staff estimates and projections as of July 7, 1999.

1/ Contribution to GDP growth.

2/ Based on normalized unit labor costs; $1990=100$. 
Table 2. Japan-General Government Operations, 1996-1999

(In percent of GDP)

\begin{tabular}{|c|c|c|c|c|c|c|c|c|}
\hline & FY 1996 & FY 1997 & $\begin{array}{l}\text { FY } 1998 \\
\text { Est. }\end{array}$ & $\begin{array}{l}\text { FY } 1999 \\
\text { Proj. }\end{array}$ & CY 1996 & CY 1997 & $\begin{array}{l}\text { CY } 1998 \\
\text { Est. }\end{array}$ & $\begin{array}{l}\text { CY } 1999 \\
\text { Proj. }\end{array}$ \\
\hline General government balance & -4.1 & -3.4 & -6.1 & -7.6 & -4.2 & -3.4 & -5.3 & -7.7 \\
\hline $\begin{array}{l}\text { Excluding social security } \\
\text { Of which: }\end{array}$ & -6.6 & -5.9 & -8.3 & -9.7 & -6.8 & -5.9 & -7.5 & -9.8 \\
\hline Taxes and fines & 18.1 & 18.3 & 17.6 & 16.8 & 18.2 & 18.2 & 17.9 & 16.8 \\
\hline Consumption & 9.6 & 9.9 & 10.1 & 10.2 & 9.7 & 9.7 & 10.1 & 10.2 \\
\hline Investment & 6.2 & 5.7 & 6.2 & 6.2 & 6.6 & 5.7 & 5.9 & 6.5 \\
\hline $\begin{array}{l}\text { Change in structural balance } \\
\text { (including social security) } \\
\text { Impact on aggregate demand }\end{array}$ & $\begin{array}{r}-1.0 \\
0.3\end{array}$ & $\begin{array}{r}1.6 \\
-1.1\end{array}$ & $\begin{array}{r}-1.5 \\
0.4\end{array}$ & $\begin{array}{r}-1.0 \\
0.8\end{array}$ & $\begin{array}{r}-1.5 \\
1.2\end{array}$ & $\begin{array}{r}1.1 \\
-1.1\end{array}$ & $\begin{array}{l}-0.3 \\
-0.5\end{array}$ & $\begin{array}{r}-2.0 \\
1.8\end{array}$ \\
\hline
\end{tabular}

Source: Staff estimates, based on the following assumptions:

Growth: Real GDP growth is projected to be -2.8 percent in CY 1998 and 0.2 percent in CY 1999. Each percentage point increase in growth raises the general government balance by about 0.3 percentage points of GDP.

Stimulus Packages: The projections take account of the FY 1999 initial budget, and the $¥ 24$ trillion stimulus package announced in November 1998. The November package is assumed to raise public investment by $¥ 4$ trillion through CY1999, most of which will take place in the first half of the year. Local governments are projected to largely offset their share in jointly financed projects in the stimulus package with cuts in own-account expenditures elsewhere. Of the $¥ 9.3$ trillion in tax cuts, $¥ 3 / 4$ trillion is assumed to occur in the first quarter of CY1999, and the bulk of the remainder in FY1999. The projection also includes a $¥ 500$ billion suplementary budget for FY1999.

Support for Banks: Under Japanese fiscal accounting, the budgetary impact of capital made available to the DIC for dealing with bank closures and for capital injections occurs at the time that the money is spent. In addition to the measures already taken, a capital injection of $¥ 2 \frac{1}{2}$ trillion to the banks is assumed to occur in FY1999.

Impact of Aggregate Demand: These calculations assume that changes in the structural component of taxes and transfers have an elasticity of $1 / 2$ while changes in consumption and investment spending have an elasticity of 1.2. Net lending and capital transfers, including land acquisition and the injection of capital into the banking system, have a multiplier of zero. The calculations include the impact of changes in the social security balance and changes in public enterprise investment. 
Table 3. Japan: Comparison Between Current Baseline Forecast and Low Growth Scenario

(Fiscal year basis; in percent of GDP, unless otherwise noted)

\begin{tabular}{|c|c|c|c|c|c|c|}
\hline & 1997 & 1998 & 1999 & 2000 & 2005 & $\begin{array}{l}\text { Average } \\
2001-05\end{array}$ \\
\hline \multicolumn{7}{|l|}{ Current baseline forecast } \\
\hline Real GDP growth (percent) & -0.5 & -2.0 & -- & 1.7 & 1.5 & 2.4 \\
\hline General government balance & -3.4 & -6.1 & -7.6 & -7.0 & -0.7 & -2.9 \\
\hline (excluding social security) & -5.9 & -8.3 & -9.7 & -9.1 & -3.3 & -5.4 \\
\hline Primary balance & -2.4 & -4.9 & -6.1 & -5.3 & 1.1 & -1.1 \\
\hline Structural balance & -3.0 & -4.5 & -5.5 & -5.2 & -0.7 & -2.5 \\
\hline (excluding social security) & -5.7 & -7.2 & -8.4 & -8.0 & -3.3 & -5.3 \\
\hline Gross debt & 101.1 & 117.9 & 129.0 & 139.6 & 154.2 & $\ldots$ \\
\hline Net debt & 19.5 & 30.5 & 38.2 & 45.6 & 54.5 & $\ldots$ \\
\hline Net debt (excluding social security) & 65.7 & 80.2 & 89.9 & 99.2 & 113.1 & $\ldots$ \\
\hline \multicolumn{7}{|l|}{ Low growth scenario } \\
\hline Real GDP growth (percent) & -0.5 & -2.0 & - & 0.7 & 1.0 & 1.0 \\
\hline General government balance & -3.4 & -6.1 & -7.6 & -7.3 & -7.0 & -7.2 \\
\hline (excluding social security) & -5.9 & -8.3 & -9.7 & -9.4 & -9.0 & -9.4 \\
\hline Primary balance & -2.4 & -4.9 & -6.1 & -5.6 & -4.6 & -5.0 \\
\hline Structural balance & -3.0 & -4.5 & -5.5 & -5.1 & -4.1 & -4.6 \\
\hline (excluding social security) & -5.7 & -7.2 & -8.4 & -8.0 & -7.2 & -7.8 \\
\hline Gross debt & 101.1 & 117.9 & 129.0 & 140.5 & 183.2 & $\ldots$ \\
\hline Net debt & 19.5 & 30.5 & 38.2 & 46.0 & 77.8 & $\ldots$ \\
\hline Net debt (excluding social security) & 65.7 & 80.2 & 89.9 & 99.9 & 138.7 & $\cdots$ \\
\hline
\end{tabular}

Source: Staff calculations. 
JAPAN-FUND RELATIONS

(As of May 31, 1999)

I. Membership Status: Joined 8/13/52; Article VIII

II. General Resources Account:

Quota

Fund holdings of currency

Reserve position in Fund

Operational budget transfers (net)

III. SDR Department:

Net cumulative allocation

Holdings

IV. Outstanding Purchases and Loans:

V. Financial Arrangements:

VI. Projected Obligations to Fund:

VII. Exchange Rate Arrangement:
SDR Million

$13,312.80$

$7,480.15$

$5,832.92$

217.00

SDR Million

891.69

$1,881.75$
\% Quota

100.0

56.2

43.8

\% Allocation

100.0

211.0

None

None

None

Japan maintains an exchange system that is free of restrictions on the making of payments and transfers for current international transactions, with the exceptions of restrictions maintained against Iraq and Libya, pursuant to UN Security Council Resolutions 661 and 748. These restrictions were notified to the Fund (EBD/90/261) in accordance with Executive Board Decision No. 144-(52/51). Restrictions against former members of the Federal Republic of Yugoslavia (Serbia/Montenegro) have been lifted. 


\section{JAPAN—DATA ISSUES}

1. Japan's economic data generally meet the criteria for coverage, periodicity and timeliness specified in the Fund's Special Data Dissemination Standard (SDDS), although Japan has made use of a flexibility option on the timeliness of dissemination of data on general government operations (see below).

\section{National accounts}

- "Quick estimates" of Japan's quarterly GDP data are released by the Economic Planning Agency (EPA) about 2 months and 10 days following the end of the relevant quarter-similar to many industrial countries, but slower than the U.S., U.K. and that planned for the E.U. ${ }^{21}$ The approximate publication date is not available until one week in advance of the data release. More complete annual national accounts data are only available with a lag of about one year, severely limiting their usefulness for current analysis. ${ }^{22}$

- The GDP data on some key components of demand are available only with the release of the annual data, including the breakdown of trade flows into goods and services, of business investment into structures and equipment, and of private consumption into durable and nondurables.

- There are no "quick estimates" for the income side of the national income accounts (with the exception of household employment income). This is in part because estimates for profits are based on an imputed quarterly pattern for annual data.

- The procedures used to seasonally adjust the quarterly GDP data do not appear to fully account for "trading-day" effects and other shift factors. ${ }^{23}$

- The EPA relies on other agencies and organizations to compile the underlying source data used to construct the national accounts, and it faces coordination problems with data providers in influencing the design of surveys and administrative collections to serve national accounts purposes.

\footnotetext{
${ }^{21}$ Following a recent report on the use of more rapid "flash" estimates of GDP, the EPA will release internally constructed "flash" estimates at the same time as the "quick" estimates, so the public can be made aware of the differences in results.

${ }^{22}$ The data are available in hard copy after a delay of about nine months, however they are not released electronically until about one year has passed.

${ }^{23}$ This problem contributed to sharp swings in quarterly GDP growth in the first quarter of 1996 and, more recently, may have had a similar impact in the first quarter of 1999.
} 
- The methodology used to construct the quick estimates of GDP from the underlying data is not well understood outside of the EPA. ${ }^{24}$

\section{Fiscal}

- $\quad$ Fiscal accounts typically distinguish between general (or ordinary) accounts for core government functions, and special accounts that are partly financed through borrowing from the FILP. Information on the general account is readily available, but the consolidated accounts which incorporate special accounts are insufficient to calculate a consolidated deficit as borrowing is included in revenues.

- Moreover, there exist more than 3,000 independent prefectures and municipalities, the finances of which are only partly consolidated with a delay of about two years.

- Data on general government operations are available only with the release of the annual national accounts data, implying a lag of up to a year and a half in assessing overall government operations. ${ }^{25}$

- The disaggregation of the fiscal data by major government sector is subject to a further lag-the fiscal data by sector for FY1998 will not be available electronically until April 2000.

\section{External trade}

- While monthly data on merchandise trade and the balance of payments are released on a timely basis, there is no predetermined schedule for their release.

- Movements in the unit value series for exports and imports have frequently differed sharply from those in trade price indices produced by the Bank of Japan.

\footnotetext{
${ }^{24} \mathrm{~A}$ recent report recommended that the methodology used by the EPA be disclosed.

${ }^{25}$ Japan intends to take the "flexibility option" in this area, meaning that it would not meet the criteria for timeliness specified in the SDDS. Comprehensive fiscal data of the general government sector are particularly important in Japan, given the importance of special accounts, local government operations, the Fiscal Investment Loan Program, and other items that are not included in the general account of the central government.
} 


\section{Household spending and labor market activity}

- The definition of employment and labor force participation in the labor force survey differ from standardized OED definitions, which may lead to an understatement of the unemployment rate.

- There are concerns about a recent deterioration in the quality of survey data on household consumption spending due to declining response rates and possible sampling biases.

\section{Monetary and financial sector}

- The data on monetary and credit aggregates are generally satisfactory, although Japan has chosen to make use of the "extensive branch banking network" flexibility of the DDS and will continue to disseminate banking sector data with a 5-6 week timeliness rather than the 4 weeks called for by the Standard.

- The need to improve disclosure of asset quality and balance sheet data for financial institutions is discussed in the main text.

\section{Recommendations for data improvements}

In the short term, consideration should be given to several steps to improve the quality of Japan's data:

- improving the timeliness and periodicity of the fiscal data (particularly given the importance of monitoring fiscal consolidation efforts on a comprehensive basis);

- $\quad$ publishing more timely estimates of quarterly GDP data;

- $\quad$ providing greater detail on the quarterly components of spending and national income;

- $\quad$ setting fixed release dates for key data, including the national accounts and external trade;

- improving the seasonal adjustment of the national accounts and other important economic data;

- releasing more information on the methodology used to construct the national accounts from other economic indicators.

Initiatives that would be desirable over the longer term include:

- bringing Japan's definition of labor market activity into line with OECD standardized definitions;

- moving Japan's data production to a single, independent agency staffed with professional statisticians. 


\section{Japan-Survey of Reporting of Main Statistical Indicators}

(As of end-June 1999)

\begin{tabular}{|c|c|c|c|c|c|c|c|c|c|c|c|c|}
\hline & $\begin{array}{c}\text { Exchange } \\
\text { Rates }\end{array}$ & $\begin{array}{c}\text { Inter- } \\
\text { national } \\
\text { Reserves }\end{array}$ & $\begin{array}{c}\text { Reserve/ } \\
\text { Base } \\
\text { Money }\end{array}$ & $\begin{array}{l}\text { Central } \\
\text { Bank } \\
\text { Balance } \\
\text { Sheet }\end{array}$ & $\begin{array}{l}\text { Broad } \\
\text { Money }\end{array}$ & $\begin{array}{c}\text { Interest } \\
\text { Rates }\end{array}$ & $\begin{array}{l}\text { Consumer } \\
\text { Price Index }\end{array}$ & $\begin{array}{l}\text { Exports/ } \\
\text { Imports }\end{array}$ & $\begin{array}{c}\text { Current } \\
\text { Account } \\
\text { Balance }\end{array}$ & $\begin{array}{c}\text { Overall } \\
\text { Government } \\
\text { Balance }\end{array}$ & $\begin{array}{l}\text { GDP/ } \\
\text { GNP }\end{array}$ & $\begin{array}{l}\text { External } \\
\text { Debt/ } \\
\text { Debt } \\
\text { Service }\end{array}$ \\
\hline $\begin{array}{l}\text { Date of latest } \\
\text { observation }\end{array}$ & $6 / 30 / 99$ & $5 / 99$ & $3 / 99$ & $6 / 21 / 99$ & $5 / 99$ & $6 / 30 / 99$ & $5 / 99$ & $5 / 99$ & $4 / 99$ & 1997 & 1999:Q1 & End-1998 \\
\hline Date received & $6 / 30 / 99$ & $6 / 99$ & $6 / 99$ & $6 / 28 / 99$ & $6 / 99$ & $6 / 30 / 99$ & $6 / 99$ & $6 / 99$ & $6 / 99$ & $4 / 99$ & $6 / 99$ & $5 / 99$ \\
\hline $\begin{array}{l}\text { Frequency of } \\
\text { data }\end{array}$ & $\mathrm{D}$ & $\mathrm{M}$ & $\mathrm{M}$ & $\begin{array}{l}\text { Every } 10 \\
\text { days }\end{array}$ & $\mathrm{M}$ & $\mathrm{D}$ & $\mathrm{M}$ & $\mathbf{M}$ & $\mathrm{M}$ & A & $\mathbf{Q}$ & A \\
\hline $\begin{array}{l}\text { Frequency of } \\
\text { reporting }\end{array}$ & $\mathrm{D}$ & M & $\mathrm{M}$ & $\begin{array}{c}\text { Every } 10 \\
\text { days }\end{array}$ & $\mathrm{M}$ & $\mathrm{D}$ & M & M & M & A & $Q$ & A \\
\hline Source of data & C & C & C & $\mathrm{C}$ & C & $\mathrm{C}$ & $\mathrm{C}$ & $\mathrm{C}$ & $\mathrm{C}$ & $\mathrm{C}$ & $\mathrm{C}$ & $\mathrm{C}$ \\
\hline $\begin{array}{l}\text { Mode of } \\
\text { reporting }\end{array}$ & $E$ & $\mathrm{E}$ & $E$ & $\mathrm{E}$ & $\mathrm{E}$ & $E$ & $\mathrm{E}$ & $E$ & $\mathrm{E}$ & $E$ & $\mathrm{E}$ & $\mathrm{E}$ \\
\hline Confidentiality & $\begin{array}{l}\text { Unre- } \\
\text { stricted }\end{array}$ & $\begin{array}{l}\text { Unre- } \\
\text { stricted }\end{array}$ & $\begin{array}{l}\text { Unre- } \\
\text { stricted }\end{array}$ & $\begin{array}{l}\text { Unre- } \\
\text { stricted }\end{array}$ & $\begin{array}{l}\text { Unre- } \\
\text { stricted }\end{array}$ & $\begin{array}{l}\text { Unre- } \\
\text { stricted }\end{array}$ & $\begin{array}{l}\text { Unre- } \\
\text { stricted }\end{array}$ & $\begin{array}{l}\text { Unre- } \\
\text { stricted }\end{array}$ & $\begin{array}{l}\text { Unre- } \\
\text { stricted }\end{array}$ & $\begin{array}{l}\text { Unre- } \\
\text { stricted }\end{array}$ & $\begin{array}{l}\text { Unre- } \\
\text { stricted }\end{array}$ & $\begin{array}{l}\text { Unre- } \\
\text { restricted }\end{array}$ \\
\hline $\begin{array}{l}\text { Frequency of } \\
\text { publication }\end{array}$ & $\mathrm{D}$ & $\mathrm{M}$ & $\mathrm{M}$ & $\begin{array}{l}\text { Every } \\
10 \text { days }\end{array}$ & $\mathrm{M}$ & $\mathrm{D}$ & $\mathrm{M}$ & $\mathrm{M}$ & $\mathrm{M}$ & A & $Q$ & A \\
\hline
\end{tabular}


1. This statement provides an update of information that has become available since the release of the staff report (SM/99/165, 7/12/99). It covers: recent monthly data and the short-term outlook; exchange rate developments; fiscal policy plans; the package of measures to support corporate restructuring; proposals for reform of the public pension system; and information on the situation of regional banks and the deposit insurance system.

\section{Monthly data for June seem broadly consistent with GDP remaining flat or} declining moderately in the second quarter, somewhat stronger than anticipated earlier. Retail sales data suggest that private consumption has continued to rise, exports look to be picking up, and a strong increase in industrial production in June limited the decline of this variable in the second quarter to 1 percent. Nevertheless, a sharp quarterly drop in capital goods shipments suggests that business investment has renewed its decline. Moreover, a rise in the unemployment rate to a record 4.9 percent and a sharp drop in bonus payments in June may dampen consumer sentiment in the second half of 1999 , when the recovery will already be under pressure from the expected contraction in public investment. Even so, there now looks to be some room to raise the staff's current 0.2 percent projection for GDP growth in calendar 1999, which at present is just above the consensus.

3. Views on the outlook for $\mathbf{2 0 0 0}$ remain widely dispersed. Like the staff, a number of forecasters expect a pick-up in growth based on a turnaround in business investment together with a positive contribution from the external sector, provided that macroeconomic policies remain supportive. However, many observers are more pessimistic, concerned that corporate restructuring will continue to have a negative impact on private demand and that there may be a significant withdrawal of fiscal stimulus. The consensus forecast growth in 2000 is still below zero, compared to the staff's projection of 1 percent growth.

4. Since mid-July, the yen has risen to around $¥ 114$ to the U.S. dollar, an appreciation of almost 6 percent (around 4 percent in nominal effective terms). Market reports suggest that exchange market intervention-largely sterilized - has continued over this period but in reduced amounts in the face of broader downward pressures on the dollar. Officials have emphasized that the overall policy towards the yen remains unchanged, and that a premature strengthening of the exchange rate would be undesirable.

5. Recently approved guidelines for drawing up the FY2000 budget have increased the need for a substantial second FY1999 supplementary budget. The first supplementary budget for FY1999-authorizing $¥ 500$ billion of spending related to the June 11 jobs package- has now been passed by the Diet. On July 30, the Cabinet approved guidelines for the FY2000 initial budget which imply about a $2 \frac{1}{2}$ percent increase in general account appropriations compared to the initial budget for FY1999 (on an equivalent basis). Nevertheless, on this basis, actual outlays in FY2000 could fall significantly because FY1999 disbursements are being boosted by the large supplementary budget announced in late 1998 . 
A decision on the scale of a possible second FY1999 supplementary budget is expected in September, after release of the second quarter GDP results.

6. In mid-July, the cabinet approved a package of tax and administrative measures to support industrial revitalization. The package is intended to support the scrapping of current production facilities, the streamlining of business organization, and the exploitation of new markets by firms engaged in a serious restructuring effort. Incentives include:

- Tax benefits including an extension of the carry forward period for losses related to scrapping capital from five years to seven years, reduction of registration and licensing taxes applied to transfer of assets, and accelerated depreciation allowances for new investments in specific assets.

- Exemptions from commercial law requirements to streamline approvals for divestiture of subsidiaries and affiliates.

- Raising the upper limit on the issue of preferred stocks from one third to one half of all stocks to facilitate debt-equity swaps.

- Increasing the upper limit on the use of stock option schemes from 10 percent of total stocks to 25 percent.

- Providing financial support for management and employee buy-outs to facilitate stock purchases.

- Low interest loans and loan guarantees to encourage new businesses, drawing on the pool of funds already established in October 1998.

Corporations wanting to benefit from the measures would be required to submit business restructuring plans to the Government, which should be approved before end-March 2001. Legislation has been sent to the Diet and is expected to be passed by mid-August.

7. It is too early to assess the overall impact of this package. Many of the details - such as criteria for eligibility-remain to be worked out in detail. Care will be needed to ensure that application is nondiscriminatory. Moreover, it will be important to follow through with broad-based and permanent reforms of the legal and tax framework.

8. In mid-July, the cabinet approved pension reform legislation for submission to the Diet. The bills include measures to raise gradually the minimum age for earnings-related pensions from the current 60 to 65 , to adopt a new formula that will tend to limit increases in the salary-based portion of pension payments to new retirees from April 2000, and to reduce pension payments to those aged between 65 and 70 who continue to work. Based on these changes, official estimates suggest that the employee pension insurance contribution rate would need to rise from its current rate of 17.4 percent of base wages to 27.6 percent by 2025 to ensure the viability of the pension system; this compares to a 34.5 percent contribution rate 
needed by 2025 for viability under the current framework. The LDP and the Liberal Party also agreed to expand the government's share of funding for the basic pension program from the current one-third to one-half, provided that specific funding for this increase (which would cost about $¥ 2$ trillion or 0.4 percent of GDP) can be identified. The legislation is likely to be considered in the Diet this fall. Similar reforms for pensions to public sector employees were also recently recommended, while plans are also proceeding to introduce $401(\mathrm{k})$ style defined contribution schemes from next year, which will help to encourage labor mobility.

9. Recent data on the financial position of regional banks confirm the weak position of this sector. The results recently announced for the special examination of first tier regional banks conducted by the Financial Supervisory Agency showed that on average provisions were about one third less than those thought appropriate by FSA inspectors. Results for second tier regional banks-not yet announced-may well be considerably worse. Moreover, even before adjusting for higher needed provisioning, the capital adequacy ratio of about half of the regional banks is less than 8 percent, the Basle standard for international banks.

\section{Continuing concern for the weak financial situation of the banking system is} focussing attention on the reform of the deposit insurance system. The Financial System Council issued an interim report in early July setting out a broad set of issues to be addressed in returning to partial deposit insurance coverage scheduled for April 2001. The final report is expected by the end of the year, with a view to tabling legislation by early 2000 . Difficult issues to be addressed include the possible need for flexibility to respond to any recurrence of systemic pressures and the design of effective methods for dealing with failed institutions (the current framework expires at end-March 2001). A separate problem is that the $¥ 7$ trillion specifically set aside in the March 1998 legislation to compensate losses in failed institutions through March 2001 is quite likely to be exhausted by the resolution of the Long-Term Credit Bank (LTCB) and the Nippon Credit Bank (NCB), implying a need for additional public funding. 
This page intentionally left blank

CInternational Monetary Fund. Not for Redistribution 


\section{INTERNATIONAL MONETARY FUND}

Public Information Notice

EXTERNAL

RELATIONS

DEPARTMENT

Press Information Notice (PIN) No. 99/75

FOR IMMEDIATE RELEASE

International Monetary Fund

August 13, 1999

Washington, D. C. 20431 USA

\section{IMF Concludes Article IV Consultation with Japan}

On August 4, 1999, the Executive Board concluded the Article IV consultation with Japan.1

\section{Background}

Japanese growth has been lackluster through most of the 1990s. Since the asset price bubble burst in 1991, the economy has grown at an average of 1 percent per annum, in striking contrast to the rapid growth achieved in previous decades. This disappointing performance has occurred despite expansionary macroeconomic policies. A series of fiscal stimulus packages raised the structural general government deficit by more than 5 percentage points of GDP between FY1991 and FY1998, while monetary policy has been progressively eased, with the overnight call rate being reduced from more than 8 percent in 1991 to effectively zero at present.

After a short-lived recovery in 1996, the economy moved back into recession in early 1997. The downturn was initiated by a larger-than-anticipated fall in household spending after the April 1997 consumption tax hike, compounded by a sharp reduction in domestic bank lending partly associated with disruptive impact of the failure of three major financial institutions in late 1997, and the Asia crisis. GDP declined almost 3 percent in 1998, with all of the main components of private domestic demand experiencing far deeper and more prolonged declines than in previous recessions. However, a surge of public investment starting in the fourth quarter of 1998, together with steps to ease financial constraints, contributed to stabilize private demand and a pick-up in output in the first quarter of 1999.

\footnotetext{
'Under Article IV of the IMF's Articles of Agreement, the IMF holds bilateral discussions with members, usually every year. A staff team visits the country, collects economic and financial information, and discusses with officials the country's economic developments and policies. On return to headquarters, the staff prepares a report, which forms the basis for discussion by the Executive Board. At the conclusion of the discussion, the Managing Director, as Chairman of the Board, summarizes the views of Executive Directors, and this summary is transmitted to the country's authorities. In this PIN, the main features of the Board's discussion are described.
} 
The drop of business investment over the past two years has been particularly severe. By the fourth quarter of 1998, business investment was almost 20 percent below its early 1997 peak. To an important extent, the abrupt decline has reflected continued efforts to address excess indebtedness and over-investment inherited from the "bubble" period. More generally, an increasing focus on profitability rather than market share and reduced expectations of long-term growth encouraged firms to cut-back plans for capital accumulation. Limits on the availability of bank credit also seem to have been a negative factor, although recently this constraint has been alleviated by policy actions.

Private consumption has been dampened by falling incomes and concerns about labor market adjustment. Even with tax cuts, disposable income has declined about $11 / 2$ percent over the past year, while expectations of future earnings have been undermined by a rising unemployment rate and by prospects for further increases in the period ahead as a number of major corporations have announced employment reduction plans. Against this, the receding threat of financial crisis has been a positive influence on consumer sentiment, which may partly explain a modest pick-up in spending in early 1999.

Support from external demand has receded. Export volumes declined through 1998 and into the first quarter of 1999, despite the moderating impact of the downturn in Asian trade, as the boost to exports to other parts of the world coming from earlier yen depreciation waned. Real imports also fell through 1998, mainly reflecting weak domestic demand. The current account surplus rose 1 percentage point of GDP to 31/4 percent of GDP in 1998, boosted by declining oil prices and the J-curve effect from yen appreciation in the second half of the year.

Deflationary pressures have so far remained moderate. Excluding the impact of falling commodity prices, the 12-month rate of decline of the WPI has been about $1 \frac{1}{2}$ percent, not very different from the average rate of decline during the 1990s. The 12-month change in the core $\mathrm{CPI}$ (excluding fresh food and energy) has been slightly negative since last fall.

Responding to increasing evidence of weak activity, the authorities have acted to inject substantial fiscal stimulus. A $¥ 16.7$ trillion ( 3 percent of GDP) package of public works and temporary income tax cuts in April 1998 was followed by a $¥ 24$ trillion (5 percent of GDP) package in November, including permanent cuts in personal and corporate income tax rates, increased credit guarantees for bank loans to SMEs, temporary consumption vouchers, and a further boost to public works spending. The FY1999 budget confirmed the expansionary overall fiscal stance, and included additional tax incentives aimed at boosting residential investment and investment in information technology. A further $¥ 500$ billion package of measures to support employment creation and retraining was announced in June 1999.

The Bank of Japan (BOJ) has continued to ease monetary conditions over the past year by cutting interest rates and supporting credit intermediation, while other government financial institutions have also been mobilized to relax financing constraints. The target rate in the overnight call market was steadily eased and by March 1999 had been reduced to virtually zero. In April, the Governor announced that this "zero interest rate policy" would be sustained until deflationary concerns were dispelled. Stepped-up BOJ participation in commercial paper (CP) repo operations have been used to facilitate corporate financing while public funds have been provided to increase the availability of loan guarantees from local government credit guarantee associations. 
Exchange rate policy has been geared to resisting movements in the yen to extreme levels and avoiding unstable market conditions. In the context of turbulent global market conditions which prompted an easing of U.S. monetary policy and an unwinding of yen carry trade positions, the yen appreciated during the second half of 1998 , and reached $¥ 109$ per dollar in early January 1999. Subsequently, the further easing of monetary policy together with exchange market intervention encouraged the yen to depreciate, and it moved around $¥ 120$ per dollar during most of the first half of 1999 . However, upward pressures on the yen resumed in June and July in the context of positive economic news and a more generalized downward movement in the U.S. dollar.

A framework for dealing with banking problems has now largely been put in place, reducing immediate concerns for systemic risk. In October 1998, the government set aside $¥ 60$ trillion (12 percent of GDP) for financial support for banks. The 15 major banks received $¥ 7.5$ trillion in capital injections in early 1999, based on detailed restructuring plans. The newly-created Financial Supervisory Agency (FSA) has effectively increased regulatory pressure on banks while the new framework for dealing with failed institutions was used to proactively nationalization of the Nippon Credit Bank in late 1998 and, more recently, the placing of three second-tier regional banks under government administration based on the results of FSA audits. However, the changes have not yet gone far enough to fully resolve banks' balance sheet and profitability problems.

Structural reforms over the past year have mainly focussed on the financial sector and changes to promote corporate restructuring. The "Big Bang" financial reforms have remained on schedule and are now nearing completion. These reforms are being complemented by the progressive introduction of improved accounting standards and accelerated plans to reform insolvency law. A package of tax and regulatory measures to promote corporate restructuring were announced in July 1999.

Despite the strong first quarter rebound, a sustained recovery is not yet assured. The staff's current forecast is for $1 / 4$ percent growth in 1999 rising to 1 percent in 2000 . The monthly indicators of activity for the second quarter suggest a continued rise in private consumption, but business investment looks likely to have renewed its decline. Moreover, rising unemployment may dampen consumer sentiment in the second half of 1999, when the recovery will already be under pressure from the expected contraction in public investment. Nevertheless, the staff expects growth to pickup in 2000 based on a turnaround in business investment and a positive contribution from the external sector, provided that macroeconomic policies remain supportive.

\section{Executive Board Assessment}

Executive Directors observed that over the last year and a half the Japanese authorities had implemented a wide-ranging series of fiscal, monetary, and banking initiatives to support the economy and relieve financial strains. These actions had contributed importantly to the emerging signs of a bottoming out of activity and a turnaround in business confidence and market sentiment, and had averted the immediate threat of a deflationary spiral. Despite these benefits, however, Directors believed that the economic outlook remained uncertain. In this connection, they noted that the financial and corporate restructuring now in progress could continue to weigh on both business investment and household spending in the short term, although such restructuring was vital to restore the vigor and profitability of Japanese business. 
Directors endorsed the government's evolving strategy, which gives increased emphasis to promoting restructuring efforts, while maintaining macroeconomic support. Most Directors felt that, while the scope for additional fiscal and monetary stimulus is now limited, it is still too early to start unwinding the support for aggregate demand from macroeconomic policies, given the uncertain short-term prospects. Directors also underscored that recent signs of improvement in activity should not detract from efforts to foster the resolution of underlying structural problems in the banking and corporate sectors, without which an effective expansion of credit to the private sector, and an enduring recovery overall, would not be possible.

Within this framework, most Directors suggested that, notwithstanding the longer-term need for fiscal consolidation, the present supportive fiscal stance should be sustained until a recovery in private demand takes hold. Some Directors expressed concern that the recent surge in public investment spending could be reversed in the second half of the year, particularly given financial constraints on local governments, and that the recently announced budgetary guidelines for fiscal year $\mathbf{2 0 0 0}$ could imply a considerable fiscal tightening in that year. Given the uncertain outlook for private demand, they suggested that a substantial further supplementary budget would be needed for fiscal year 1999 to ensure that fiscal stimulus is not withdrawn prematurely. Many other Directors, however, felt that the potential benefits from continued expansionary fiscal policy were limited, raising concerns about the productivity of recent public investment projects, pointing to the implications of further large fiscal packages for Japan's already high debt-to-GDP ratio, and stressing that, more fundamentally, an enduring recovery would depend on determined implementation of structural reforms. Some Directors also drew attention to the need to gear any short-term fiscal expansion to enhancements in the efficiency of fiscal policy, consistent with the objective of longer-term fiscal consolidation.

While continuing macroeconomic uncertainty means that it is too early to lay out a detailed road map for long-term fiscal adjustment, Directors emphasized that it would be critical to push ahead with fiscal reforms to lay the groundwork for eventual consolidation once a self-sustaining recovery is achieved. They suggested that priorities should include comprehensive reforms to ensure the long-term viability of the public pension system; extending recent initiatives to increase the efficiency of public works spending; and tax reforms to assist labor mobility, support corporate restructuring, and broaden the tax base. Directors also emphasized that greater fiscal transparency would increase the public's understanding of the intended fiscal policy stance, and thus enhance the economy's responsiveness to fiscal policy initiatives.

Directors commended the Bank of Japan's (BOJ) commitment to maintaining a zero interest rate policy until deflationary concerns are dispelled, and emphasized that monetary policy is providing critical support for the economy, thereby helping to alleviate immediate deflationary concerns. In the unlikely event that price declines intensify significantly, several Directors suggested that the BOJ would need to find ways to apply additional monetary stimulus, for example, by extending monetary operations up the yield curve and broadening the range of assets involved in such operations. While noting the recent significant measures to increase transparency, some Directors felt that further steps would be especially appropriate in such circumstances, for example, by making the BOJ's long-term inflation objectives more explicit and adopting a supplementary operating target to signal intended changes in the monetary policy stance. Other Directors felt that current procedures provided a high degree of flexibility for monetary policy and did not need to be changed. 
Many Directors felt that a substantial strengthening of the yen could undermine the recovery, and felt that the authorities should, in the short term, resist sustained upward pressure on the currency. Several Directors observed, in this connection, that a stable yen would also be conducive to promoting the recoveries of the crisis-affected countries in the region. However, some Directors felt that recent upward pressure on the yen was the natural result of improved prospects for Japan, and that intervention aimed at resisting this market response could interfere with the process of adjustment over time to existing large global current account imbalances, as well as with carrying forward the necessary structural reforms at home. A number of Directors felt that intervention, in any case, might not be effective, even if it was unsterilized.

Directors complimented the authorities on the effective framework for resolving banking system problems that has now been put in place, which has reduced the immediate risk of financial turbulence. They underscored that the focus now needs to turn to implementation, noting that the current environment of greater stability in the banking system offers Japan the opportunity to pursue a more aggressive strategy in tackling banking system weaknesses. Directors emphasized the need for further initiatives to restore the banking sector to full health and raise profitability toward international levels, particularly in light of the planned return to partial deposit insurance after March 2001. They suggested that by this date the minimum capital adequacy standard for all banks should be raised to 8 percent, consistent with the Basle standard, although this would need to be implemented gradually to moderate any initial negative impact on bank lending. Moreover, a robust structure for deposit insurance needs to be in place by this time, including a well-financed insurance fund and efficient mechanisms to deal with failed institutions.

While recognizing progress over the past year to tighten bank supervision, Directors emphasized that the restoration of the banking system to full vigor would require continued pressure on banks to classify loans appropriately and to raise provisioning against impaired loans, particularly since recent weakness in activity had probably contributed to the further deterioration of loan portfolios. Regulators would also need to ensure that banks that have received public capital injections achieve their performance objectives. In addition, a number of Directors considered that every effort needs to be made to ensure that nationalized banks are quickly returned to the private sector, including by selling marketable assets of the banks separately to investors if buyers cannot be quickly found for such banks as going concerns, and to ensure that public bodies given the task of disposing of nonperforming loans act expeditiously, before the value of their assets erodes further.

Directors were pleased to note that the Big Bang financial reforms are now nearly complete and are already catalyzing changes in the financial system. Welcoming the increasing attention being paid by the government to structural issues, they suggested that priority now be given to pushing through further initiatives to strengthen the financial system, enhance the environment for corporate restructuring, foster greater labor mobility, and accelerate deregulation. Steps to reduce the public sector's role in financial intermediation and strengthen further the regulation of the broader financial system, including the troubled life insurance sector, would complement the Big Bang reforms. Directors welcomed recent steps to support corporate restructuring by reducing legal and regulatory impediments, and by accelerating plans to reform the bankruptcy code to provide a more flexible approach to corporate rehabilitation. In this connection, some Directors attached particular importance to improving corporate governance. Directors also 
emphasized the need to provide increased impetus to deregulation efforts through comprehensive sectoral programs. In the view of many Directors, the potential short-term strains in labor markets from restructuring could be relieved by steps to enhance the flexibility of the labor market.

A number of Directors observed that Japan's economic data in some areas suffered from important weaknesses, which complicate the monitoring of developments in the formulation of macroeconomic policies. They encouraged the authorities to place a high priority on improving the timeliness and coverage of these statistics.

Directors commended Japan for its continuing role as the world's largest provider of official development assistance. They particularly welcomed the initiatives taken over the past year to provide increased financial support to East Asian crisis countries, which have played an important part in fostering a strong regional recovery.

Directors welcomed the authorities' decision to participate in the pilot project for the release of Article IV consultation staff reports.

Public Information Notices (PINs) are issued, (i) at the request of a member country, following the conclusion of the Article IV consultation for countries seeking to make known the views of the IMF to the public. This action is intended to strengthen IMF surveillance over the economic policies of member countries by increasing the transparency of the IMF's assessment of these policies; and (ii) following policy discussions in the Executive Board at the decision of the Board. As part of a pilot project, the staff report (use the free Adobe Acrobat Reader to view this pdf file) for the 1999 Article IV consultation with Japan is also available on the IMF's website (http://www.imf.org). 
Japan: Selected Economic Indicators

\begin{tabular}{|c|c|c|c|c|c|}
\hline & 1995 & 1996 & 1997 & 1998 & $\begin{array}{l}\text { Proj. } \\
1999\end{array}$ \\
\hline & \multicolumn{5}{|c|}{ Percent changes, unless otherwise noted } \\
\hline GDP & 1.5 & 5.0 & 1.4 & -2.8 & 0.2 \\
\hline Private consumption & 2.1 & 2.9 & 1.0 & -1.1 & 0.8 \\
\hline Nonresidential investment & 5.2 & 11.3 & 7.1 & -11.3 & -6.0 \\
\hline Residential investment & -6.5 & 13.6 & -16.3 & -13.7 & -5.7 \\
\hline Public investment & 0.6 & 9.2 & -10.4 & -0.3 & 14.2 \\
\hline Public consumption & 3.3 & 1.9 & 1.5 & 0.7 & 1.5 \\
\hline Stock building $1 /$ & 0.2 & 0.4 & -0.1 & -0.1 & -0.2 \\
\hline Foreign balance (contribution) & -0.8 & -0.5 & 1.4 & 0.6 & -0.2 \\
\hline Exports & 5.4 & 6.3 & 11.6 & -2.3 & -0.5 \\
\hline Imports & 14.2 & 11.9 & 0.5 & -7.5 & 1.1 \\
\hline \multicolumn{6}{|l|}{ Inflation } \\
\hline GDP deflator & -0.6 & -1.4 & 0.1 & 0.3 & 0.0 \\
\hline $\mathrm{CPI}$ & -0.1 & 0.1 & 1.7 & 0.6 & -0.2 \\
\hline Unemployment rate (period average) & 3.1 & 3.3 & 3.4 & 4.1 & 5.0 \\
\hline Industrial production & 3.4 & 2.3 & 3.6 & -7.1 & 0.1 \\
\hline \multicolumn{6}{|l|}{ Current account balance } \\
\hline Billions of U.S. dollars & 111.4 & 65.8 & 94.1 & 121.0 & 143.1 \\
\hline Percent of GDP & 2.2 & 1.4 & 2.2 & 3.2 & 3.5 \\
\hline \multicolumn{6}{|l|}{ General government balances (percent of } \\
\hline Balance including social security & -3.6 & -4.2 & -3.4 & -5.3 & -7.7 \\
\hline Structural balance & -3.0 & -4.6 & -3.5 & -3.8 & -5.8 \\
\hline Balance excluding social security & -6.5 & -6.8 & -5.9 & -7.5 & -9.8 \\
\hline Structural balance & -6.0 & -7.1 & -6.0 & -6.5 & -8.6 \\
\hline \multicolumn{6}{|l|}{ Monetary aggregates } \\
\hline M1 & 8.2 & 13.7 & 8.8 & 8.5 & $\ldots$ \\
\hline $\mathrm{M} 2+\mathrm{CDs}$ & 3.2 & 3.2 & 3.0 & 4.4 & $\cdots$ \\
\hline \multicolumn{6}{|l|}{ Exchange rates (period average) } \\
\hline Yen/dollar rate & 94.1 & 108.8 & 121.0 & 130.9 & $\ldots$ \\
\hline Real effective exchange rate $2 /$ & 151.1 & 127.7 & 120.0 & 110.2 & ... \\
\hline \multicolumn{6}{|l|}{ Interest rates (period average) } \\
\hline 3-month $C D$ & 1.1 & 0.5 & 0.5 & 0.4 & $\ldots$ \\
\hline 10-year bond & 3.3 & 3.0 & 2.1 & 1.3 & $\ldots$ \\
\hline
\end{tabular}

Sources: Nikkei Telecom and IMF staff estimates.

1/ Contribution to GDP growth.

2/ Based on normalized unit labor costs; $1990=100$. 